\title{
QUEEN'S
QNIVERSITY
BELFAST
}

\section{Comparative Analysis of High Voltage Gain DC-DC Converter Topologies for Photovoltaic Systems}

Amir, A., Amir, A., Che, H. S., Elkhateb, A., \& Rahim, N. A. (2018). Comparative Analysis of High Voltage Gain DC-DC Converter Topologies for Photovoltaic Systems. Renewable Energy.

https://doi.org/10.1016/j.renene.2018.09.089

\section{Published in:}

Renewable Energy

\section{Document Version:}

Peer reviewed version

\section{Queen's University Belfast - Research Portal:}

Link to publication record in Queen's University Belfast Research Portal

\section{Publisher rights}

Copyright 2018 Elsevier.

This manuscript is distributed under a Creative Commons Attribution-NonCommercial-NoDerivs License

(https://creativecommons.org/licenses/by-nc-nd/4.0/), which permits distribution and reproduction for non-commercial purposes, provided the author and source are cited.

\section{General rights}

Copyright for the publications made accessible via the Queen's University Belfast Research Portal is retained by the author(s) and / or other copyright owners and it is a condition of accessing these publications that users recognise and abide by the legal requirements associated with these rights.

Take down policy

The Research Portal is Queen's institutional repository that provides access to Queen's research output. Every effort has been made to ensure that content in the Research Portal does not infringe any person's rights, or applicable UK laws. If you discover content in the Research Portal that you believe breaches copyright or violates any law, please contact openaccess@qub.ac.uk. 


\title{
Comparative Analysis of High Voltage Gain DC-DC Converter Topologies for Photovoltaic Systems
}

\author{
Asim Amir a , Aamir Amir a, Hang Seng Che ${ }^{\text {a }}$, Ahmad El Khateb ${ }^{\text {b }, ~ N . A . ~ R a h i m ~ a, c, * ~}$ \\ ${ }^{a}$ UM Power Energy Dedicated Advanced Centre (UMPEDAC), Level 4, Wisma R\&D, University of Malaya, \\ Jalan Pantai Baharu, 59990 Kuala Lumpur, Malaysia \\ ${ }^{b}$ School of Electronics, Electrical Engineering and Computer Science, Queen's University Belfast, Belfast BT9 \\ $5 A H, U K$ \\ ${ }^{c}$ Renewable Energy Research Group, King Abdulaziz University, Jeddah 21589, Saudi Arabia \\ *Corresponding author: nasrudin@um.edu.my
}

ARTICLE INFO

ARTICLE HISTORY:

KEYWORDS:

DC-DC converter,

High voltage gain techniques

(HVGT),

Non-isolated transformer less converters (TL),

Isolated DC-DC converters.

\begin{abstract}
In this paper, a comparative analysis has been presented on various topologies of isolated and non-isolated DC-DC converters. Here, the major focus remains on transformer-less (TL) DC-DC converters, based on the conventional basic boost converter. In addition, to attain high voltage gain, a classification of non-isolated converters based on extendable and non-extendable design has been presented. For comparative and theoretical analysis, the parameters chosen are the number of components utilized by each converter topology, high voltage gain offered, voltage stresses on each component involved and the efficiency of the high gain topologies. For the converters under discussion, operation under ideal and non-ideal conditions has also been highlighted. Based on this study, authors present a guide for the reader to identify various high voltage gain topologies for photovoltaic (PV) systems.
\end{abstract}

\section{Contents}

1. Introduction

2. Isolated DC-DC Converter Topologies

3. Non-isolated DC-DC Converter Topologies

3.1. Analysis of parasitic elements in the non-isolated DC-DC converters

3.2. Non-isolated DC-DC Boost Converter with Non-Extendable Voltage gain

3.2.1. Conventional 3-level Boost Converters

3.2.2. Switched Inductor (SL) Based Boost Converter

3.2.3. Cuk Derived Boost Converter \& Zeta Derived Boost Converters

3.2.4. Active Network Based Boost Converters 


\subsection{Non-isolated DC-DC Boost Converter with Extendable Voltage gain}

3.3.1. Cascaded Boost Converter

3.3.2. Multiport Based Boost

3.3.3. Super Lift Voltage converter (SLVC) \& Modified Voltage Lift Converter (MVLC)

3.3.4. Cockcroft Walton Multiplier Based Boost Converter \& Dickson Multiplier Based Boost Converter

3.3.5. Boost derived MIESC SC-cell converter \& buck-boost derived MIESC SC-cell converter

3.3.6. Hybrid Boosting Converter

3.3.7. Boost Converters with Coupled Inductor

3.3.8. 3-State Switching-based Boost Converter

3.3.9. Interleaved Boost-based Converters

\subsection{Switched Capacitor based DC-DC Boost Converter with Extendable Voltage gain \\ 3.4.1. Input Voltage response at high duty ratio \\ 3.4.2. Input Voltage response near MPP \\ 3.4.3. Input Voltage response at low duty ratio}

\section{Discussion \\ 5. Conclusion References}

\section{Introduction}

In photovoltaic (PV) systems, high gain voltage is favorable. As in uninterruptible power supplies (UPS) and micro PV inverter [1-8]. For such applications, low input voltage from (PV) source need to be stepped-up. For example, in micro PV inverter, interfacing PV panel with a $230 V_{R M S}$ grid requires the low PV voltage (typical around $30 V_{D C}$ ) to be stepped up to around 375-400 $V_{D C}[5,9-19]$. For such applications, the voltage boosting required is too high to be achievable using conventional basic boost DC-DC converter topology, hence there remains a necessity for modified topologies offering high voltage gain. DC-DC converters commonly been divided into isolated and non-isolated topologies. For isolated DC-DC converters high voltage transformers $(H V T)$ are utilized as presented in [4, 20-26]. Typically, for such converters high gain voltage boosting can be attained by $H V T$ with high turn's ratio and by using voltage multipliers [16, 27-30]. Considering the case of full-bridge converters based on Phase-Shifted (PS) PWM, Zero-voltage (ZVS) and Zero-current (ZCS) switching can attained by utilizing leakage inductance of the $H V T$. The drawbacks of such a design include that the leakage inductance of HVT induces eddy current and excessive current on the primary of the transformer possibly decreasing the life span of PV panels. In addition, high current and voltage spikes on the secondary of the HVT, necessitates diodes with high breakdown voltage at output, as the voltage stress on the diodes remains greater than the output voltage [31-35]. Such shortcoming decrease the overall efficiency of the isolated converters.

In contrast, size and weight of the converter can be sizably reduced and higher efficiency offers a similar high voltage gain can be attained by employing TL DC-DC converters [35, 36]. Conventional boost and the buck-boost converters [34, 37-46]. For various applications Ćuk, SEPIC and Zeta topologies are preferred over conventional buck-boost converter for their better efficiency and continuous input current [47-52], albeit having higher component count [53]. Some attempts to create hybrid converters by crossover structures including the boost and the Ćuk topologies, but at expense of the extra components devoid of enhancing voltage gain characteristics $[28,50]$. The boost converter usually has higher efficiency than the SEPIC [52]. In any case, boost converters output voltage is constantly higher than the input, which offers means of rigidity in power extraction [52, 54-59]. 
Despite many different topologies, the conventional boost converter still enjoys considerable amount of popularity due to the following advantages: few number of components which translate into system cost reduction; non-pulsating input current (if the converter operated in continuous-conduction mode $(C C M)$ ) and simple drive circuit.

By contrast, the major demerit of basic boost converter is the limited voltage gain. To further elaborate, in order to accomplish high voltage gain in basic boost converter, switch must conduct for $90-95 \%$ of the total time, consequently; sharp current spikes for short time and high current stress harass the switch over the entire conduction time. On the other side, the diode conducts for 5-10\% of the total time, diode suffers severe reverse recovery problems. Additionally, the parasitic resistive elements inherited with the components in the circuit further constrain the voltage gain and the overall efficiency of the converter. The main losses of power occur due to; switching losses. Secondly, to construct a converter of this nature, a high voltage rating diode is required which causes severe diode reverse recovery problems. Thirdly, copper losses and core losses in the inductor $[32,35,38,46,60-66]$.

In light of aforementioned issues, considerable amount of work has been dedicated to enhance voltage gain and the overall efficiency of boost converter, as seen in the available literature. So, to attain high voltage gain, various voltage multiplying techniques have been introduced, where they allow the modified boost converters to have extendable voltage gain. Many review articles have been published on DC-DC converter topologies [26, 67-80], however, none of the articles has presented a classification of the non-isolated DC-DC converters based on the design for extendable or non-extendable voltage gain. This paper brings most of the topologies together and categorizes them comparative and theoretical analysis. By classifying the topologies based on their theoretical achievable voltage gain, this paper attempts to give better insights to the performances and drawbacks of the converters, and hence help users or researchers in determining the most suitable converter topology based on their desired voltage gain range.

The objectives of the review are as follows:

1. Present a wide range of isolated and non-isolated DC-DC converters, which have been neglected by various review articles.

2. Classify the non-isolated DC-DC converters based on the design for extendable or non-extendable voltage gain.

3. A comparative review between different DC-DC converters, by theoretically analyzing each converter under discussion, particularly focusing the non-isolated design.

4. Guide for future work on DC-DC converter topologies, by displaying the pros and cons of the mentioned topologies.

The remaining of this paper is structured in the following manner: Section 2 Highlights the isolated DC-DC converter designs. Subsequently, Section 3 comparatively analyze the non-isolated DC-DC converters, focusing various modified topologies based on conventional boost converter with extendable and non-extendable voltage gain designs. Section 4 discusses the merits and demerits of all the converters under consideration. Finally, Section 5 provides the concluding remarks.

\section{Isolated DC-DC Converter Topologies}


Fig. 1 presents only the chief isolated and non-isolated converters. In order to connect energy sources offering lower input voltages with a DC - Bus at higher voltage, galvanically isolated DC-DC converters are one of the most promising options available [4, 20-26]. For such converters, this isolation protects the source from high voltage variations at the load. Such converters offer effectual utilization of the energy source, wider load regulations and possess the capability to work with a broader variety of input voltages.

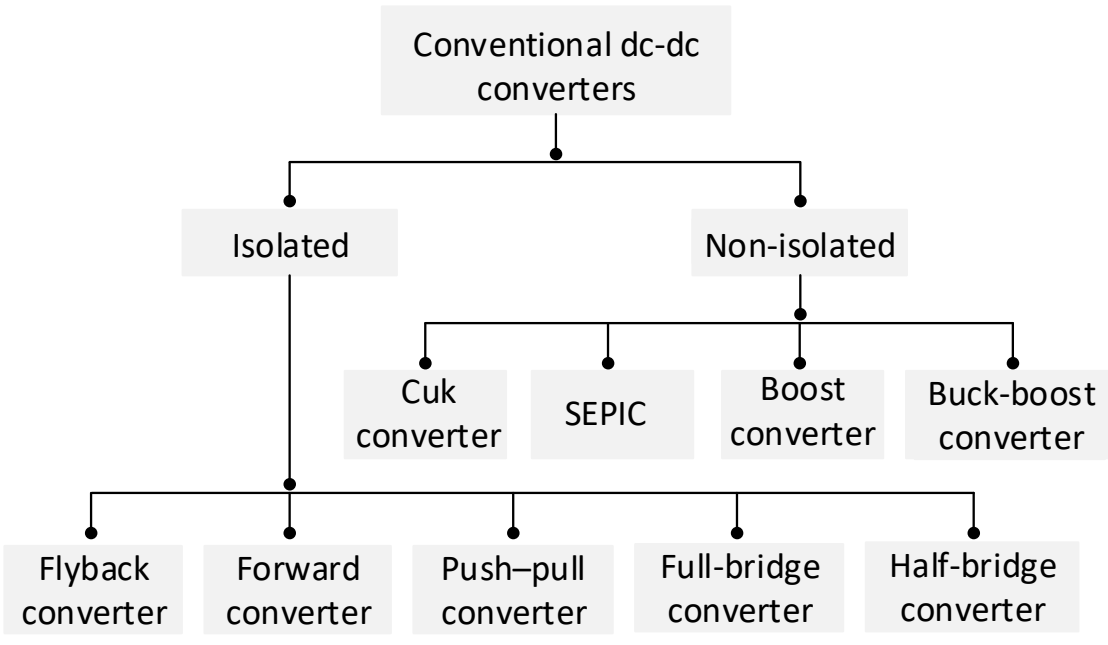

Fig. 1. Isolated and non-isolated DC-DC converts.

\section{Non-isolated DC-DC Converter Topologies}

\subsection{Analysis of parasitic elements in the non-isolated DC-DC converters}

In this paper, the major focus remains of non-isolated DC-DC converter topologies. For the case of nonisolated converters by utilizing semiconductor and passive components ideally, there is a probability to attain high voltage gain against duty cycle. Section 3 presents various modified approaches for non-isolated high voltage gain DC-DC converters. Starting from the most fundamental topological design, Fig. 2(a) presents the schematic diagram of the basic boost converter and Fig. 2(b) the equivalent diagram of the conventional boost converter. In this paper, the power stage is highlighted in red color, rectifier stage in blue and the switched capacitor stages in black. Here, the parasitic elements have also been considered to evaluate the gain and efficiency of the converter.

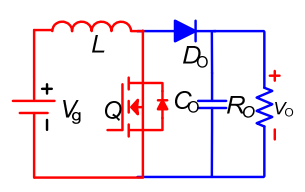

(a)

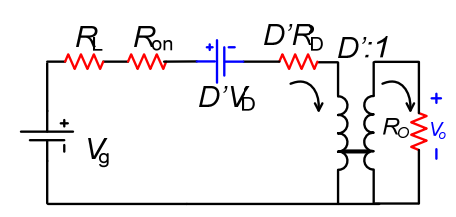


(b)

Fig. 2. (a) Basic boost converter, (b) equivalent circuit of the boost converter.

Theoretically, by utilizing the volt-second balance, the analysis of the basic boost converter can be done. Here, current charge balance principles in continuous conduction mode $(C C M)$ of operation have also been highlighted. As,

$\left\langle V_{L}\right\rangle=D\left(V g-I R_{L}-I R_{o n}\right)+(1-D)\left(V g-I R_{L}-V_{D}-I R_{D}-V_{o}\right)=0$

$\left\langle i_{C}\right\rangle=D \cdot\left(V / R_{o}\right)+(1-D) \cdot\left(I-V / R_{o}\right)=0$

Where,

$D$ is the duty cycle, $R_{\mathrm{o}}$ remains the load resistance, $V_{g}$ input voltage and $V_{o}$ remains the output voltage. Nonideal inherent resistive elements, have also been considered, corresponding to the diode resistance $R_{D}$, diode threshold voltage $V_{D}$, series inductor $R_{L}$ and the switch $R_{o n}$

$V g^{-I R} L^{-I D R_{o n}}-(1-D) \cdot V_{D^{-I}}-(D-1) R_{D^{-(1-D) \cdot} \cdot V_{O}}=0$

$I(1-D)-\left(V_{O} / R_{O}\right)=0$

Furthermore, it remains simple enough to express voltage gain $M=V_{o} / V_{g}$ to be given by [81]:

$M=\frac{V_{O}}{V_{g}}=\frac{1}{(1-D)}\left(1-\frac{(1-D) V_{D}}{V_{g}}\right)\left(\frac{(1-D)^{2} R_{O}}{(1-D)^{2} R_{O}+R_{L}+D R_{o n}+(1-D) R_{D}}\right)$

Efficiency $\eta$ of the conventional boost converter can be obtained as [81]:

$\eta=(1-D) \frac{V_{O}}{V_{g}}$

$$
\eta=\left(\frac{\left(1-\frac{(1-D) V_{D}}{V g}\right)}{1+\frac{R_{L}+D R_{O n}+(1-D) R_{D}}{(1-D)^{2} \cdot R_{O}}}\right)
$$

Fig. 3(a) displays the plot for $M$ verses $D$ by equation (5) in MATLAB. Considering ideal conditions, if no parasitic resistive elements $\left(R_{L}=0, R_{o}=600, R_{o}=0, R_{D}=0, V_{D}=0\right)$ are considered, the basic boost converter offers a high voltage gain. By contrast, considering non-ideal situation where parasitic elements remain $\left(R_{o}=600\right.$, $\left.R_{o n}=0.085 \Omega, R_{D}=0, V_{D}=1.41 V_{D C}\right)$ where load resistance $R_{\mathrm{o}}$ is kept constant and the values of $R_{L}$ are gradually increased; $R_{L}=0.1, R_{L}=0.4, R_{L}=0.9$. In addition, voltage gain for the conventional basic boost converter is observed to decrease as the values for $R_{L}$ increase as shown in Fig. 3(a). 


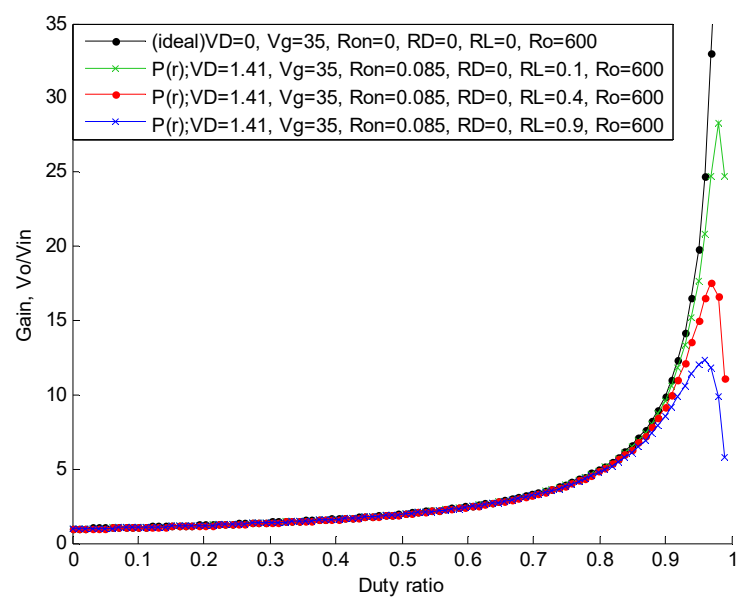

(a)

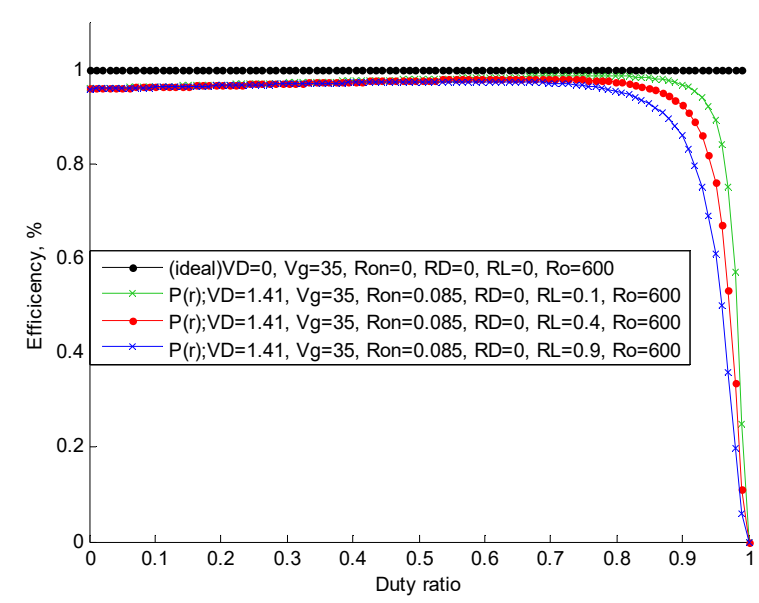

(b)

Fig. 3. (a) Plot for M verses D, and (b) plot for $\eta$ verses $D$ of the conventional boost converter.

Secondly, Fig. 3(b) displays the plot for $\eta$ verses D curve by equation (7) in MATLAB. Considering ideal conditions, the basic boost converter can achieve an efficiency of 1 which is unrealistic. By contrast, considering non-ideal situation with parasitic elements remaining $\left(R_{o}=600, R_{o n}=0.085 \Omega, R_{D}=0, V_{D}=1.41 V_{D C}\right)$ where load resistance $R_{o}$ is kept constant and the values of $R_{L}$ are gradually increased; $R_{L}=0.1, R_{L}=0.4, R_{L}=0.9$. The efficiency of the basic boost converter theoretically decreases as the values for $R_{\mathrm{L}}$ increase as shown in Fig. 3(b).

To further improve efficiency and the voltage gain, different kinds of modified TL (Transformer-less) High Voltage Gain (HVG) boost converters have been proposed based on the conventional boost converter. These topologies can be categorized as 3-state switching-based boost converters, active network-based boost converters, 3-level-based boost converters, switched capacitor-based boost converters, coupled inductor-based boost converters, cascaded-based boost converters, switched inductor-based boost converters, multiport-based boost converters, and interleaved-based boost converters, as also given in Fig. 4. These converters are further categorized into Non-extendable voltage gain and Extendable voltage gain converters. 


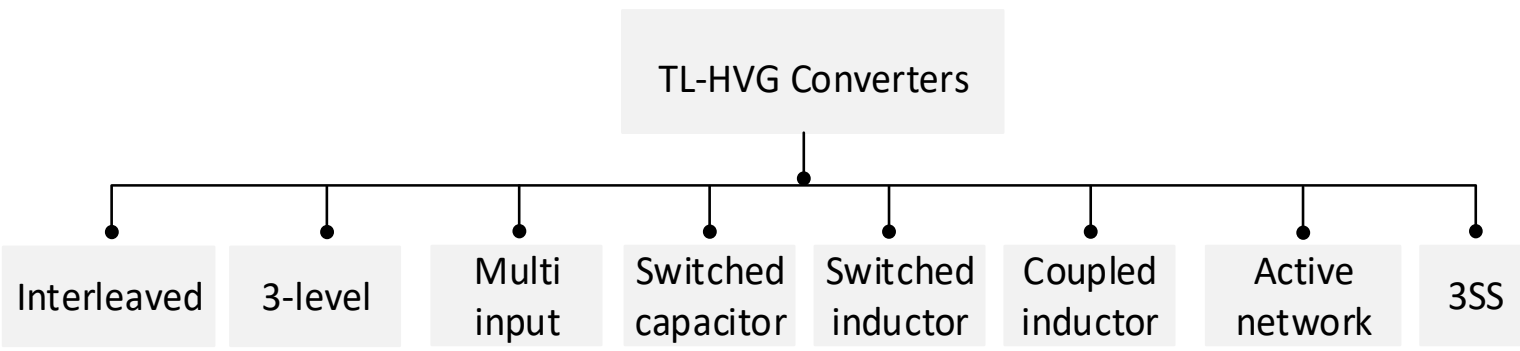

Fig. 4. Various Transformer-less High Voltage Gain Converter Topologies.

\subsection{Non-isolated DC-DC Boost Converter with the Non-Extendable Voltage gain}

\subsubsection{Conventional 3-level Boost Converters}

The conventional 3-level boost converter has been presented in Fig. 5(a). It has double the voltage gain and one-half the voltage stress on power switches as compared with conventional basic boost converter. In addition, it remains appropriate for the various low input voltage and the high output voltage applications. Moreover, the low voltage rating power devices can be utilized and switching losses minimized. By contrast, power switch has a severe output diode reverse recovery problem when it operates under the hard switching condition [82-87]. Moreover, it has a balanced output voltage which is advantages to avoid damage to the power switches, adding to this, as the voltage is balanced between both the capacitors $\mathrm{CO}_{\mathrm{O}}$ and $\mathrm{CO2}$, this feature permits the use of inverters that require capacitive divider, also this feature is advantageous in reducing common mode current circulation through the grid. On the contrary, switching frequency is low and the converter qualifies for low input voltage and high input current, therefore converter has a poor efficiency, hence it is recommended in low power applications. Single switch quadratic boost converter in Fig. 5(b) has a low efficiency, due to the effect of cascading. Quadratic 3-level boost converter in Fig. 5(c) has two stages. It has the advantages of both the topologies in Fig. 5(a) and (b). Voltage gain with high efficiency can be achieved. Therefore, it can be attractive for applications where high output power with high voltage ratio is required [88].

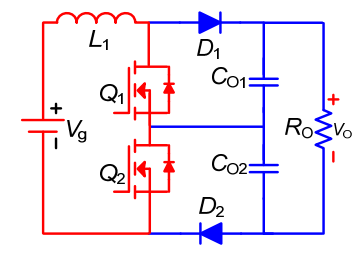

(a)

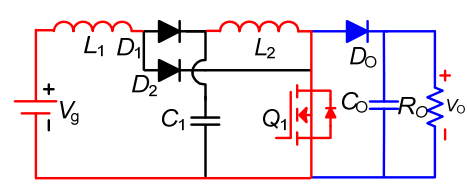

(b) 


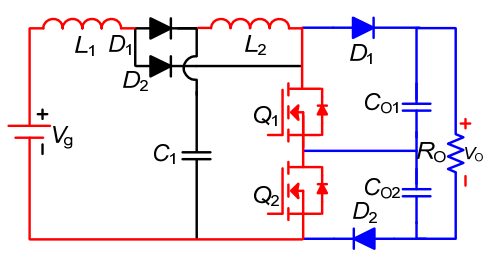

(c)

Fig. 5 (a) Conventional 3-level boost converter [82-87], (b) Single switch quadratic boost converter [85, 86] (c) Quadratic 3-level boost converter [88]

\subsubsection{Switched Inductor (SL) Based Boost Converter}

Switched Inductor $S L$-cell based Boost Converters has been presented in Fig. 6 (a), which utilizes two inductors $L_{1}$ and $L_{2}$ of equivalent inductance and employs 3 diodes $\left(D_{1}, D_{2}\right.$ and $\left.D_{3}\right)$. Advantageously, both inductor windings can be accommodated into a single core [89]. Input current is small, which allows the use of smaller inductors. Moreover, the voltage gain is higher compared to the basic boost converter. On the contrary, the voltage stress on power switch and the output diode is almost equivalent to output voltage. Also, output diode encounters reverse recovery problems. Fig. 6 (b) utilizes the $S L$-cell based technique, in which two inductors with the same inductance are employed. Using this technique the high voltage gain can be attained without using unrealistic high duty cycle. Further, voltage stress on the output diode and power switch is less than the basic boost converter, as an advantage, both the switches with the rated low voltage and the low $R_{D S(o n)}$ could be utilized in order to reduce the cost of the system.

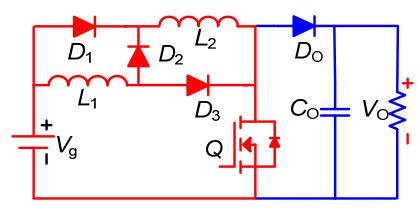

(a)

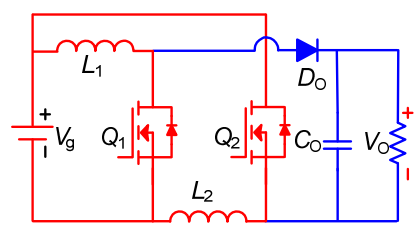

(b)

Fig. 6. (a) TL DC-DC high step-up converter [89], (b) High step up SL-based boost converter [90].

\subsubsection{Cuk Derived Boost Converter \& Zeta Derived Boost Converters}

The basic concept follows as, when the switch is $O F F$, the capacitors charged in parallel and as switch turns $O N$, the inductor is fully charged. Now, the capacitors form a series connection to offer high voltage at the output. Different boost or buck-boost topologies can be obtained by tapping out any two of the $(A-B-C-D)$ points shown in Fig. 7. However, only two $S C$-cells can be utilized at a time. For example, if points A and B are tapped out topology Fig. 8 (b) can be realized. And, if points $C$ and $D$ are tapped out topology Fig. 8 (a) can be realized. Moreover, points $B$ and $D$ cannot be tapped out because the buck-boost capacitor $C b b 2$ is directly 
connected to the boost capacitor $\mathrm{C} b 2$. As a result, the topologies in Fig. 8 are considered non-extendable. The voltage stress on the diodes and power switch is one-half the output voltage. Furthermore, turn-on current spike of the switch is controlled owing to the minor peak reverse-recovery currents. Here, the efficiency of the system can be improved if the capacitors with lower ESR are utilized.

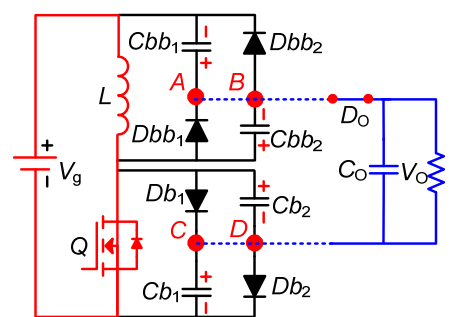

Fig. 7. Generic boost and buck-boost converters with $S C$-cell technique [8].

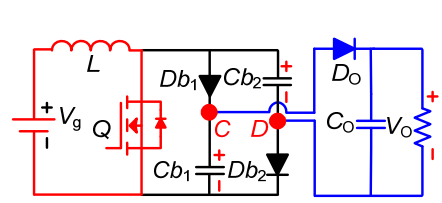

(a)

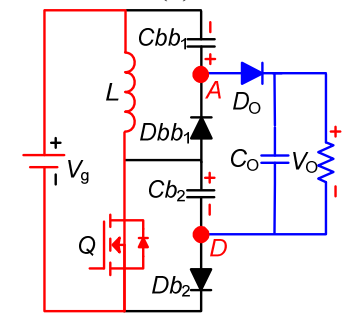

(c)

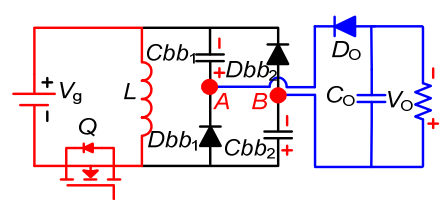

(b)

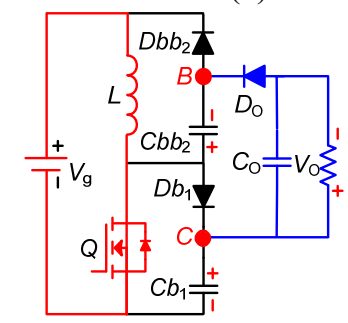

(d)

Fig. 8. (a) Ćuk derived converter [91], (b) Zeta derived converter [91] (c) Type-1 boost-buck-boost-based [91]. (d) Type-2 boostbuck-boost-based [91].

\subsubsection{Active Network Based Boost Converters}

The active-network based DC-DC converter shown in Fig. 9(a) consists of two $L_{1}$ and $L_{2}$ inductors of equivalent inductance and $Q_{1}$ and $Q_{2}$ the two switches are provided with the same gate drive signal. In addition, inductors are charged up by input source connected in parallel as switch turns on. Now, inductors form a series connection as switch turns off and charges the output capacitor $C_{O}$, offering high voltage gain at the output.

Low current and voltage stresses are observed on the power switches. Moreover, inductor current is low which can be helpful to reduce the size of inductors integrated them into single magnetic core. Here, simplest topology of $S L$ based $A N C$ has been presented in Fig. 9(b).

The winding resistance of the inductors, conduction resistance, and diode forward voltage of power devices slightly affect the voltage gain of the topology presented in Fig. 9(c). The Converter shown in Fig. 9(c) can attain high gain with a small duty cycle. The basic boost converter cannot offer such merits. This offers high voltage gain with a low voltage and a low current stress for both the controlled and uncontrolled semiconductor devices. With the reduction in such stresses the number of $S L$ and $S C$ cells can be extended as per the required gain. 


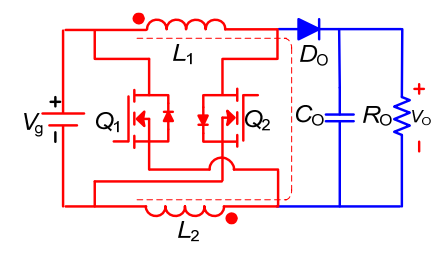

(a)

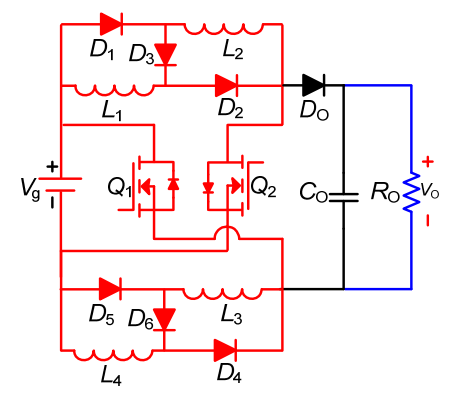

(b)

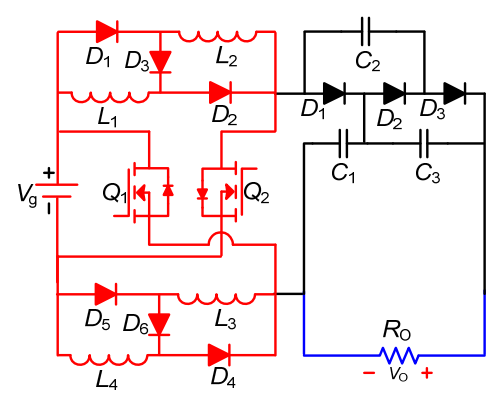

(c)

Fig. 9. (a) Active-network based DC-DC converter [90] (b) $S L$ based $A N C$ [92] (c) $S L$ and $S C$ based $A N C$ [92].

\subsection{Non-isolated DC-DC Boost Converter with Extendable Voltage gain}

For certain applications, as micro inverter, high voltage gain is necessary in order to provide sufficient voltage. Such high gain is either beyond the capability of conventional boost converter and its modified topologies. In light of this, some researchers have proposed modified TL DC-DC converters which are extendable up to $n$ stages, to have a higher voltage gain.

\subsubsection{Cascaded Boost Converter}

For high voltage gain, two (or more) boost DC-DC converters can be cascaded together as shown in Fig. 10. Nevertheless, this approach doubles the number of components as well as the losses when compared to conventional single stage boost converter. Higher DC-link voltage is supplied to the second stage and lower duty cycle can be used. This DC-link voltage is stepped up by the first stage by using higher duty cycle. Such a technique reduces current stress on power switch for second stage. Overall, the cascaded converters approach attains high voltage gain at the expense of higher component counts, higher cost, and degraded converter efficiency [93, 94]. 


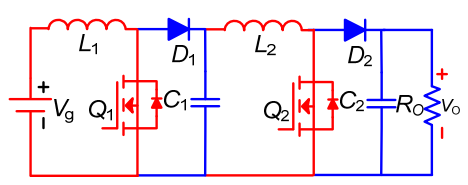

Fig. 10. Conventional cascaded boost converter [93].

\subsubsection{Multiport Based Boost Converter}

Two independent DC sources can be used to power multiport based boost converter as shown in Fig. 11 $[95,96]$. High voltage gain is achieved by cascading several switched capacitor cells which confines the voltage stresses on the semiconductor and passive components. The list of advantages above, indicate that this converter can be in favorable and good solution if integrated with solar panels as DC micro-grid. Traditional approaches, suggest connecting several panels in series to achieve a voltage of $400-\mathrm{V}$ on the DC bus, as the PV panel offers low output voltage. However, dependability of a system of this type always decline. Moreover, such a decline can be addressed by connecting individual PV panels to the converters with high voltage gain capability [97]. Further, multiport converter with an advancement of the interleaved boost input and Cockcroft Walton (CW) voltage multiplier also have been proposed in the literature in $[98,99]$. It is observed that current fed converters are far better when compared with voltage fed equivalent as they offer minimal input current ripple [99]. However, for $\mathrm{CW}$ based converters with the increase of multiplying stages, output impedance increases rapidly [100]. This counts a major demerit of the topology. Here, output impedance is the determinant of efficiency of the converter.

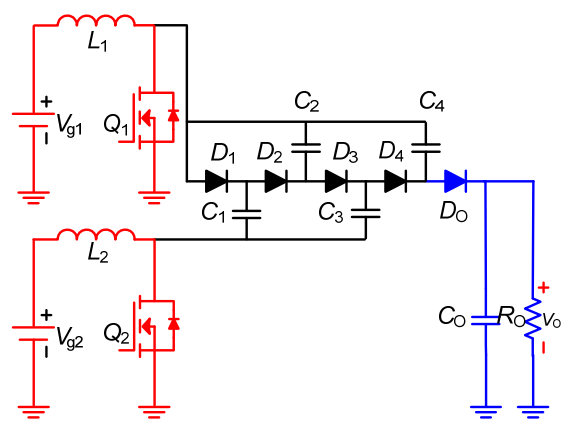

Fig. 11. High voltage gain multiport converter [101]

\subsubsection{Super Lift Voltage converter (SLVC) \& Modified Voltage Lift Converter (MVLC)}

The $S C$ cells can be extendable using super lift technique; output voltage can be increased stage-by-stage along the geometric progression. This technique is widely utilized so as to enhance high voltage gain and decline ripple voltage and current on the power components. However, input current in SVLC shown in Fig. 12(a), is not continuous. Additionally, output voltage will be affected by small load resistance by the capacitors; this may cause the currents in the circuit to increase. Secondly, the input current of the MVLC in Fig. 12(b) is continuous, which makes it most suitable for renewable energy application. The voltage gain can be further extend utilizing MVLC contrasted with conventional SVLC. In addition, when the converter operates in $C C M$, at such point voltage stresses are lower than conventional basic boost converter allowing the use of lower voltage rated diodes and switches to reduce the conduction loss. 


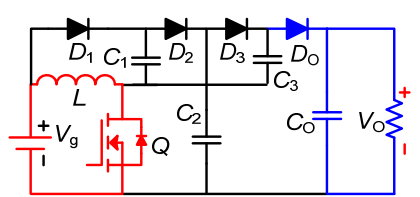

(a)

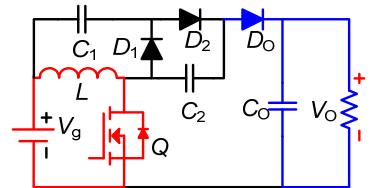

(b)

Fig. 12. (a) Super-lift with elementary circuit [102], (b) Modified voltage lifter [103]

\subsubsection{Cockcroft Walton Multiplier Based Boost Converter \& Dickson Multiplier Based Boost Converter}

Two topologies based on switched capacitor integrating the basic boost converter and Cockcroft Walton voltage multiplier and Dickson voltage multiplier have been presented in Fig.13(a and b). These techniques can add up $S C$ cells to $n$ number. Moreover, are able to overcome the problem of pulsating input current, which is absorbed by the multiplier, these topologies provide high output voltage over smaller duty cycles.

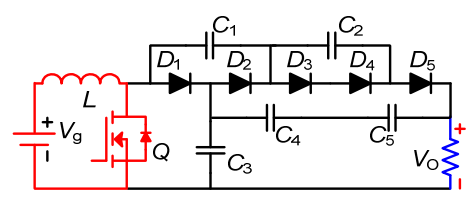

(a)

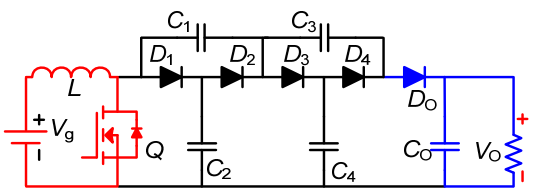

(b)

Fig. 13. (a) Dickson Multiplier Based Boost Converter [104] (b) Cockcroft Walton Multiplier Based Boost Converter [104]

\subsubsection{Boost derived MIESC SC-cell converter \& buck-boost derived MIESC SC-cell converter}

By connecting an additional $S C$ cells in series to existing cells, the voltage gain can be further increased. For instance, converter shown in Fig. 8 (a), capacitor $C_{3}$ is connected in series and one more inductor energy storage cell topology in Fig. 14 (a) can be seen. In contrast, converter shown in Fig. 8 (b), capacitor $C_{3}$ is connected in series with an additional inductor energy storage cell; topology in Fig. 14 (b) can be seen. It can be suitable for applications demanding wide input voltage range i.e. 25-45 $V_{D C}$. As the input voltage is low, the efficiency declines. As the input voltage decreases, the inductor current $i_{L}$ surprisingly increases. On the contrary, circulating current through $i_{D O}$ is independent of input voltage and considerably low. The circulating current is much smaller compared with the inductor current. Despite the fact that with minor increase in switch current, a considerable decrease in duty cycle can attained by utilizing $S C$ cells. Here, a small inductor is connected in series with output diode $D_{O}$ in order to subside current peaks as the switch is turned on. In addition, the switch dominates power loss in these converters, and the second major is the entire power loss caused due to the three diodes. However, as the $O N$ time of the switch is lesser, the switch off current and current ripple can be made smaller. This offers less switching and conduction losses, increasing the efficiency of the converter topology. However, cost for more components has to be paid to achieve a higher voltage gain. Here, only with a fewer component count high voltage gain can be attained. 


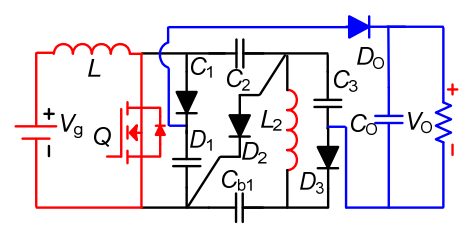

(a)

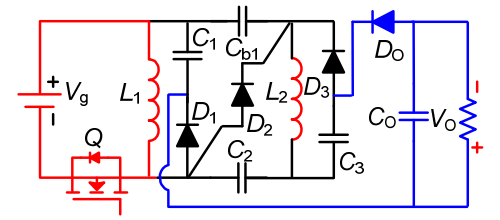

(b)

Fig. 14. (a) boost derived MIESC SC-cell converter [91] (b) buck-boost derived MIESC SC-cell converter [91]

\subsubsection{Hybrid Boosting Converter}

Hybrid boosting converter (HBC) employing bipolar voltage multiplier (BVM) is shown in Fig. 15. Characteristics of interleaving are inherited to this converter which reduces the voltage on output filter capacitor and increases utilization rate of components as the voltage gain is higher at a lower duty cycle. Topologies in $[105,106]$ utilize interleaving technique for ripple decline and power increase; however, these topologies require more components. This converter realizes minor ripples while maintains high voltage gain with only single inductor and single switch. Higher gain was archived in topologies in [107-112], but they implement two inductors and two switches. The HBC topology has the advantages such as low cost design and potential to employee in high power applications. As a disadvantage to applications where common ground is required this topology has different ground for source and load. Moreover, due to this problem audible noise may be encountered, which may necessitate a fast control loop and an input filter.

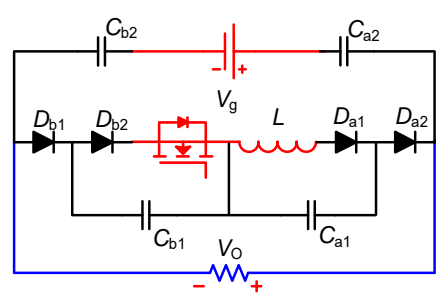

Fig. 15. Hybrid Boosting Converter [113].

\subsubsection{Boost Converters with Coupled Inductor}

Coupled inductor-based boost converters can offer high voltage gain by aptly choosing the winding ratio, moreover extreme duty cycle operation of the switch(es) can be avoided $[114,115]$. They offer reduced switch voltage stress, and low $R_{D S(o n)}$ switch and the reverse recovery for the diode at the output is improved [116-121] $[84,122]$. It's simple structure is also favorable characteristic [123-125]. However, the leakage inductance might restrain the current induction in the secondary winding, causing considerable ac conduction loss, resulting in decline of the voltage gain dominantly when the converter operating under high frequency $[114,126]$. As a solution, active clamp circuits are used in order to reprocess leakage energy to attain soft switching under the zero-voltage (ZVS) [127]. Moreover, additional clamp switch will increase topology complexity [128-130]. 


\subsubsection{Coupled Inductors with Active Clamp Circuit-based Boost Converter}

Both the switches $S_{2}$ and $S_{1}$ are assisted by the coupled inductors $L_{1}$ and $L_{2}$ and the leakage inductance of $L_{k 1}$ and $L_{k 2}$ in order to switch high with an operation under zero voltage condition (ZVS). Here, the switching low losses of switches are minimized by connecting parallel capacitors $C_{r 1}$ and $C_{r 2}$. As a result, for high voltage applications, this converter topology remain a commendable choice. In addition, appropriate turns ratio $n$ for coupled inductors must be selected with maximum duty ratio of $D=D_{\max }<0.5$. Larger value of $n$ has an effect of lower current stress on power switches thus, lower voltage stress mean switches with lower $R_{D S(o n)}$ and low voltage rated can be utilized. This converter not only has a less number of total components count also can achieve lower switching loss. Moreover, with a raise in for turns ratio $n$, as voltage stress for the diode at the output increases, thus high voltage operation may provoke high reverse-recovery losses. As a solution, an extra snubber circuit can be used to alleviate this issue [131].

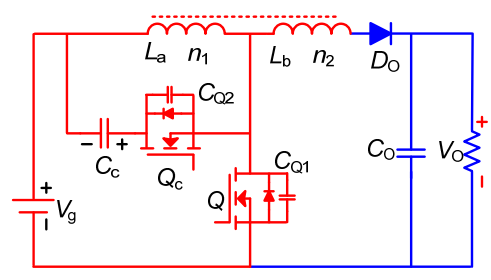

Fig. 16. Active clamp coupled-inductor-based converter [131].

\subsubsection{2. $\quad$ Single Phase Coupled Inductor Boost-based Converter with Extended Voltage Doubler}

The output diode voltage stress is reduced. In addition, a high voltage gain is attained by the extended SC. Moreover, during $O N$ state of the switch, the coupled inductor, as a transformer, transfers energy. As the switch turns off, energy is conveyed in the form of a filter inductor as shown in Fig. 17, due to this feature complete utilization of the coupled inductor is possible. As a result, magnetic core of smaller size can be utilized.

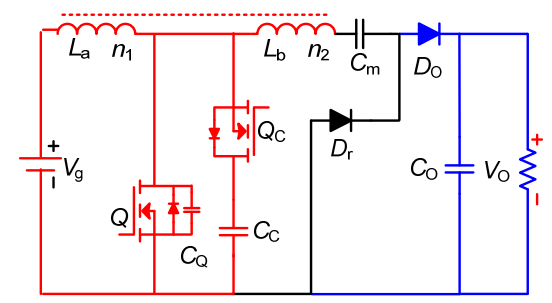

Fig. 17. Active clamp-coupled inductor-based converter [132]

\subsubsection{Coupled Inductor Multiplier with Active Clamp Circuit Based Boost Converter}

For this converter topology secondary winding of the coupled inductor is connected to a multiplier circuit. Moreover, 2 switched capacitors and 2 diodes are employed to construct the DC-DC converter as presented in Fig. 18. High voltage gain is achieved and voltage stress on the switches is reduced. Therefore, the efficiency is improved and the conduction losses are subsided. So the switches with lower $R_{D S(o n)}$ can be utilized. ZVS switching condition can be achieved, switching losses can be reduced; particularly in high-power and highfrequency applications. 


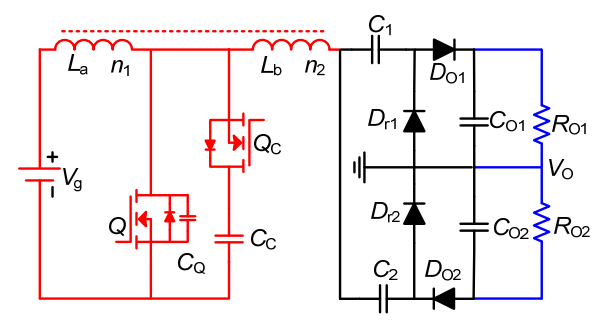

Fig. 18. Single-phase high step-up converter with coupled inductor multiplier [109]

\subsubsection{Coupled Inductor and Double Voltage Lift Capacitors-based Boost Converter.}

An amalgamation of the SC and the coupled inductor into the voltage lift technique which is based on the conventional basic boost converter has presented by this converter topology in Fig. 19. Here, magnetizing inductor and leakage inductor in the coupled inductor are symbolized as $L_{m}$ and $L_{k}$, respectively. Voltage across the switch $Q$ can be clamped as the capacitors $C_{1}$ and $C_{2}$, as the capacitors make use of the energy released byt the coupled inductor as the leakage inductor energy. As, $R_{\mathrm{DS}(\mathrm{on})}$ resistance of switch $Q$ and voltage stress is small, efficiency of the converter increases. Moreover, capacitor voltages across $C_{2}$ and $C_{3}$ are adjusted via the turns ratio of coupled inductor. High voltage gain can be achieved by reducing switch voltage stress across $Q$. Here, major operating technique is adopted from voltage-lift converts that when switch is under $O N$ condition; induced voltage $V_{S}$ on secondary side of the magnetic device, input voltage $V_{g}$ and capacitor voltage $V_{C 1}$, charge capacitor $C_{2}$. Simultaneously, capacitor $C_{3}$ is charged by induced voltage. Thus, parallel charging of capacitors $C_{2}$ and $C_{3}$ takes place. As the switch turns off, energy from the magnetic device is released and induces voltage with an opposite-polarity to the secondary side. The induced voltage $V_{S}$, input voltage $V_{g}$, in order to charge the output capacitor $C_{O}$ and $R_{O}$, capacitor voltages $V_{C 2}$ and $V_{C 3}$ are connected in series.

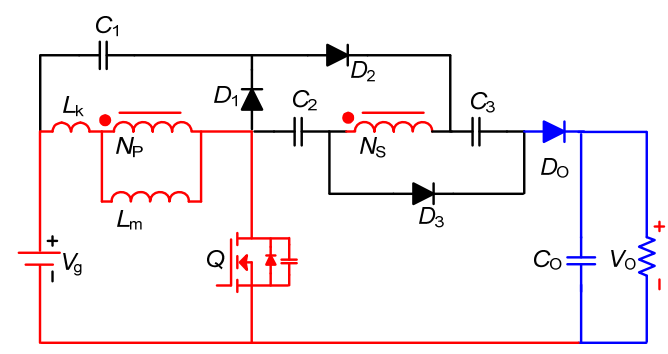

Fig. 19. Coupled inductor high voltage gain DC-DC converter [133].

\subsubsection{Single Switch converter with high step-up gain}

As presented in Fig. 20 a coupled inductor boost based DC-DC converter with only a single switch $Q$ and SC network. This topology easily achieves high voltage gain through 2-boosting capacitors $C_{b 1}$ and $C_{b 2}$, 2-switched capacitors $C_{s 1}$ and $C_{s 2}$. Moreover, leakage energy is reprocessed at output, due to which the voltage spike on switch during $O N$ time is alleviated. Here, voltage stress on power switches is $V_{O} / 3$ time less. On the plus side, power devices with lower; so that a voltage rated switch with a small $R_{D S(o n)}$ can be utilized. 


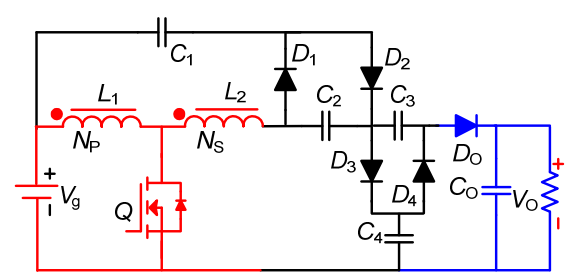

Fig. 20. Single-switch converter with high step-up gain [62]

\subsubsection{6. $\quad$ Single Switch Converter with High Step-up Gain}

Fig. 21 presents a topology which is based on two parts. Part 1 is a modified version of an interleaved boost converter and part 2 is a capacitor diode based voltage doubler combined with coupled inductor. Main functions of part 2 are; Function.1: it is able to achieve 2 times voltage gain compared to conventional interleaved boost based converter. Function.2: interleaved series connected capacitors suppress the output voltage ripple. Function.3: voltage stress on the switches $Q_{1}$ and $Q_{2}$ becomes low. In order to attain a higher voltage gain, the secondary windings are connected in series with voltage multiplier [134].

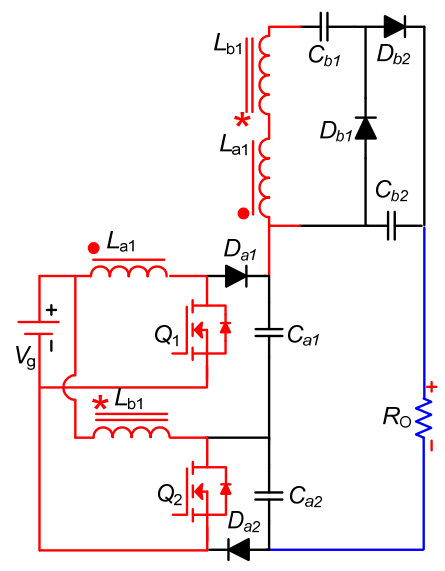

Fig. 21. High gain input-parallel output-series DC-DC converter with dual coupled inductors [134]

\subsubsection{3-State Switching-based Boost Converter}

Interleaved boost converter integrated with voltage multiplier and magnetic coupling technique carried with 3 -state switching is utilized in topology shown in Fig.22. This topology is able to attain a high voltage gain without a high turns ratio and high duty cycles. Here, even with a lower turns ratio a voltage gain similar to the conventional boost converters with coupled inductor can be attained. Moreover, the input current is shared by the primary sides of the two coupled inductors, reducing the size of the magnetic core. Also, current ripples on the switches are less which decreases the conduction loss. Furthermore, diode capacitor provides lossless passive clamp performance, also gives a raise to the voltage gain. The switches $Q_{1}$ and $Q_{2}$ are exposed to minimum voltage spikes as the leakage energy of coupled inductors is reprocessed with recursive iterations in a loop. As the voltage stress are low, low voltage rating and low $R_{D S(o n)}$ switches can be chosen. 


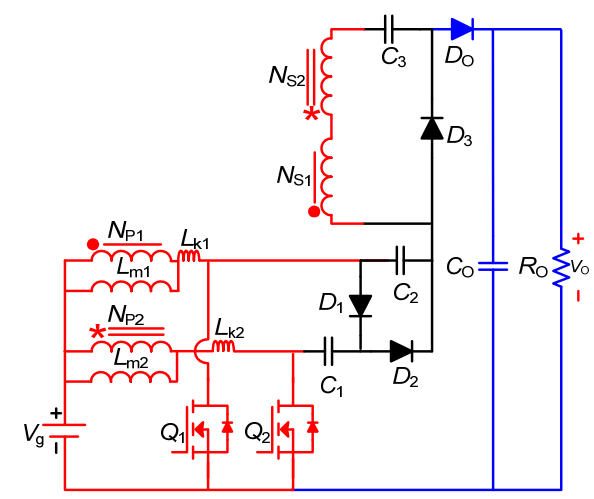

Fig. 22. Three-state switching boost converter mixed with magnetic coupling and voltage multiplier [135].

\subsubsection{Interleaved Boost-based Converters}

By increasing power level, reducing passive component size and by improving transient response the current ripple can be reduced. This topology is utilized in high power density and many large current applications.

\subsubsection{Conventional Interleaved Boost Converter}

This topology has been presented in Fig. 23 [136]. It offers a gain similar to that of the basic boost converter, at higher duty cycles, which is not favor of applications that demand high voltage gain. The on time of the switch increases and offers a larger current ripple increasing the conduction losses. Here, off time decreases and severe reverse-recovery issues are confronted by the output diode.

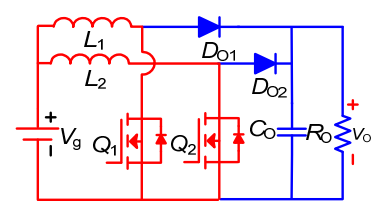

Fig. 23. Conventional interleaved boost converter [136]

\subsubsection{Interleaved Boost Converter with Voltage Multiplier}

Conventional interleaved boost is integrated with coupled inductors and $S C$-cells, as presented in Fig. 24. The coupled inductors the SC offer high voltage gain. Furthermore, conduction and diode reverse recovery losses are subsided by energy stored in the magnetizing inductor when one switches turns off, will transfer via three respective paths. Consequently, the current decreases during distribution, moreover, current through a few diodes even decrease to zero before they turn off. High-power applications can utilize this converter as it offers low conduction losses and low input current ripple increases the life span of renewable energy sources the inductors leakage current recycles to the output. Hence, large current spikes across the power switches are decreased, besides, lower voltage stresses. As a result, high efficiency with reduced cost converter is attained. 


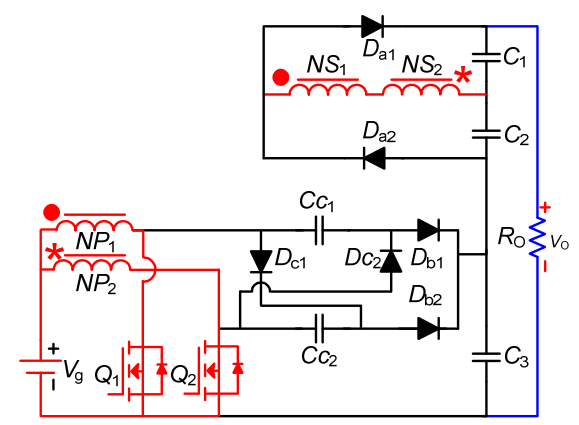

Fig. 24. interleaved boost converter with voltage multiplier [137]

\subsubsection{ZVS Interleaved boost converter}

Input current is interleaved using two inductors on the primary side in order to reduce conduction losses and current ripple of coupled inductors and across the power switch. ZVS interleaved boost converter with an active-clamping circuit is presented in Fig. 25 [138]. A SC and two coupled inductors with low turns ratio are employed to attain high voltage gain. This reduced turns ratio condenses byproducts of coupled; leakage inductance and copper losses. Additionally, voltage stresses are lessened at the output. Here, zero voltage switching $(Z V S)$ is observed as active clamping circuit is employed. Also, issue of diode reverse recovery for every diodes is alleviated. Now, higher efficiency can be expected with fewer switching losses.

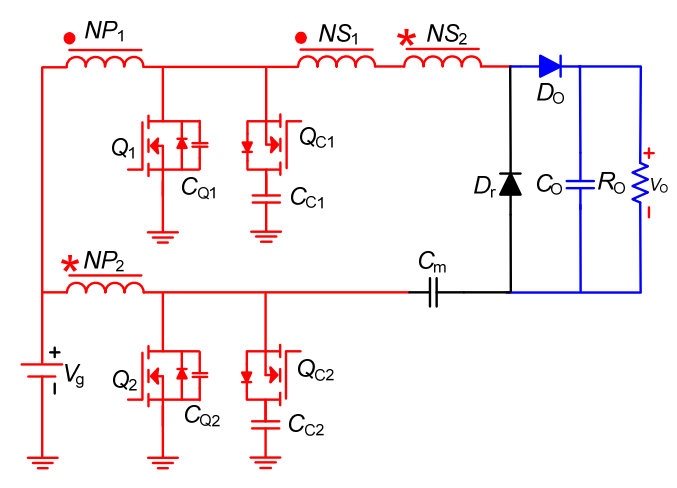

Fig. 25. ZVS interleaved TL boost converter [138]

\subsubsection{Interleaved high step up converter}

There are three windings on each core. Two coupled inductors are utilized in this topology. Where, the third winding is interleaved to the next phase as presented in Fig. 26. Here, this converter compared with the conventional boost converter can achieve high voltage gain. As the turns ratio and duty cycle increase higher voltage gain is attained. This feature allows the converter to surpass the requirement of operating the switching under extreme duty cycle, moreover the switch can avoid large peak current, as experienced by basic boost converter when utilized in high voltage applications. Additionally, voltage multiplier cells are connected in series with the power stage which creates an extra boost in high voltage gain under same duty cycle and similar turns ratio. As a result of the leakage inductance from third interleaved winding, switch $S_{1}$ and $S_{2}$ turn-on under ZCS condition, this minimizes the switching losses. Furthermore, leakage inductance from third interleaved winding reduces the output diode reverse recovery losses. 


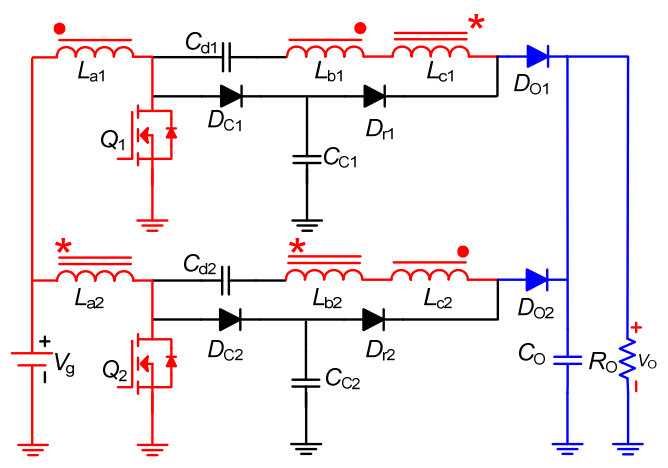

Fig. 26. Interleaved high step up converter [139]

\subsection{Switched Capacitor based DC-DC Boost Converter with Extendable Voltage gain}

Figure 27 presents an example to attain high voltage gain by incorporating 2-stage Switched Capacitor architecture to the basic boost converter. This SC converter design topology remains extendable and nonisolated. By implanting Switched Capacitor combinations with a boost converter, the switch ON time can be lessened while attaining a higher output voltage. In addition, voltage stress on the semiconductor devices is reduced. Moreover, the input current ripple is reduced as same voltage gain is achieved by utilizing lower duty cycle compared to the basic boost converter design. Table I compares the voltage gain and semiconductor component stress for both basic boost converter and 2-stage switched capacitor based boost converter. It is theoretically analyzed that by inserting a switched capacitor technique the voltage stress on the semiconductor devices can be halved against the basic boost converter.

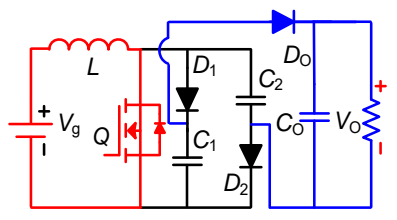

Fig. 27. 2-Stage Switched Capacitor based boost converter

TABLE I

CATEGORIZATION OF TOPOLOGIES

\begin{tabular}{|c|c|c|}
\hline Parameters & Basic boost converter & Switched capacitor based boost converter \\
\hline Gain & $\frac{1}{(1+D)}$ & $\frac{2}{(1+D)}$ \\
\hline $\begin{array}{c}\text { Switch voltage } \\
\text { stress }\end{array}$ & $V_{O}$ & $\frac{V_{O}}{2}$ \\
\hline $\begin{array}{c}\text { Diode voltage } \\
\text { stress }\end{array}$ & $V_{O}$ & $\frac{V_{O}}{2}$ \\
\hline
\end{tabular}

For a stand-alone PV system, the input voltage response of the presented 2-Stage Switched Capacitor converter operation utilizing conventional MPPT techniques $[140,141]$ can be theoretically analyzed as follows:

\subsubsection{Input Voltage response at high duty ratio}

The effective resistance seen by the source for the boost converter can be presented as: 
$R_{p v}=\frac{V_{p v}}{I_{p v}}=R(1-D)^{2}$

Similar to the conventional Boost converter, the effective resistance for the 2-Stage Switched Capacitor Boost converter can be expressed as,

$R_{p v}=\frac{V_{p v}}{I_{p v}}=\frac{R(1-D)^{2}}{4}$

Convergence rate of the input voltage can be attained as,

$\frac{\Delta V_{p v}}{\Delta D}=\frac{(D-1)}{2} k$

\subsubsection{Input Voltage response near MPP}

Similarly, the change in voltage with respected to Duty cycle, closer to MPP can be realized as,

$\frac{\Delta V_{p v}}{\Delta D}=\frac{(D-1) V_{M P P}}{(1-D)^{2}}$

\subsubsection{Input Voltage response at low duty ratio}

Further, the change in voltage with respect to Duty cycle, away from MPP at low Duty ratio can be realized as,

$\frac{\Delta V_{p v}}{\Delta D}=\frac{R}{4}\left(\frac{\Delta I_{p v}}{\Delta D}(1-D)^{2}\right)+\frac{4(2 D-2) V_{p v}}{(1-D)^{2}}$

Therefore, owing to the varying input voltage response at different duty ratio for direct control implementation of MPPT, it is necessary to consider the design and dynamics of the proposed converter while employing for PV systems.

\section{Discussion}

List of all the topologies analyzed has been presented in Table II. Moreover, the high voltage gain values, switch, output diode and multiplier diodes voltage stress for all 32 modified topologies based on the TL boost converter are noted and equations given by the authors are listed in Tables II-V. Furthermore, Table II shows the characteristics for cascaded boost converter, 3-Level, interleaved, Multiport and switched inductorbased boost converters. Table IV shows the characteristics for switched capacitor-based boost converters. Table V shows the characteristics for coupled inductor, active network and boost converter with 3 state switching.

TABLE II

CATEGORIZATION OF TOPOLOGIES

\begin{tabular}{|c|c|c|c|c|}
\hline & F & Category & \# & Topology \\
\hline \multirow{3}{*}{ 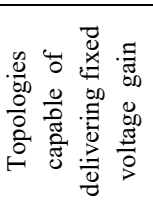 } & & Conventional boost converter & 1. & Fig. 2. (a) Conventional boost converter \\
\hline & & $\begin{array}{l}\text { Conventional 3-level Boost-based } \\
\text { Converters }\end{array}$ & 2. & Fig.5. (a) Conventional three level boost converter [82-87]. \\
\hline & & & & Fig.5. (b) Single switch quadratic boost converter $[85,86]$. \\
\hline
\end{tabular}




\begin{tabular}{|c|c|c|c|c|c|}
\hline & & & & 4. & Fig.5. (c) Quadratic three level boost converter [88]. \\
\hline & & & Switched inductor-based boost & 5. & Fig.6. (a) $S L$ boost converter [89]. \\
\hline & & & & 6. & Fig.6. (b) High step up $S L$ boost converter [90]. \\
\hline & & 4. & Switched capacitor-based boost & 7. & Fig.8. (a) Ćuk derived converter [91]. \\
\hline & & & & 8. & Fig.8. (b) Zeta derived converter [91]. \\
\hline & & & & 9. & Fig.8. (c) Type-1 boost-buck-boost-based [91]. \\
\hline & & & & 10. & Fig.8. (d) Type-2 boost-buck-boost-based [91]. \\
\hline & & & Active network-based boost converters & 11. & Fig.9. (a) Active-network based DC-DC converter [90]. \\
\hline & & & & 12. & Fig.9. (b) $S L$ based $A N C$ [92]. \\
\hline & & & & 13. & Fig.9. (c) $S L$ and $S C$ based $A N C$ [92]. \\
\hline & & & Cascaded Boost Converter & 14. & Fig.10. Conventional cascaded boost converter [93]. \\
\hline & & & Multiport-based boost converters & 15. & Fig.11. High voltage gain multiport converter [101]. \\
\hline & & 8. & Switched capacitor-based boost & 16. & Fig.12. (a) Super-lift with Elementary Circuit [102]. \\
\hline & & & & 17. & Fig.12. (b) Modified voltage lifter [103]. \\
\hline & & & & 18. & Fig.13. (a) Dickson multiplier-based boost converter [104]. \\
\hline & & & & 19. & $\begin{array}{l}\text { Fig.13. (b) Cockcroft Walton multiplier-based boost converter } \\
\text { [104]. }\end{array}$ \\
\hline & & & & 20. & Fig.14. (a) Boost derived MIESC SC-cell converter[91]. \\
\hline E & & & & 21. & Fig.14. (b) Buck-boost derived MIESC SC-cell converter[91]. \\
\hline$\stackrel{\Xi}{\Xi}$ & & & & 22. & Fig.15. Hybrid boosting converter [113]. \\
\hline$\stackrel{0}{0}$ & & & Coupled inductor-based boost & 23. & Fig.16. Active clamp coupled-inductor-based converter [131]. \\
\hline & 可 & & & 24. & Fig.17. active clamp-coupled inductor-based converter [132]. \\
\hline & $\begin{array}{l}0 \\
\text { D0 } \\
\stackrel{\Xi}{0} \\
>\end{array}$ & & & 25. & $\begin{array}{l}\text { Fig.18. single-phase high step-up converter with coupled inductor } \\
\text { multiplier [109]. }\end{array}$ \\
\hline$\frac{0}{00}$ & & & & 26. & $\begin{array}{l}\text { Fig.19. coupled inductor high voltage gain DC-DC converter } \\
\text { [133]. }\end{array}$ \\
\hline & & & & 27. & Fig.20. single-switch converter with high step-up gain [62]. \\
\hline & & & & & $\begin{array}{l}\text { Fig. } 21 . \text { High gain input-parallel output-series DC-DC converter } \\
\text { with dual coupled inductors [134]. }\end{array}$ \\
\hline & & & $\begin{array}{l}\text { Three-state switching-based boost } \\
\text { converters }\end{array}$ & & $\begin{array}{l}\text { Fig.22. 3-State Switching Boost Converter Mixed With Magnetic } \\
\text { Coupling and Voltage Multiplier [135]. }\end{array}$ \\
\hline & & 11. & Interleaved boost converters & 30. & Fig.23. Conventional interleaved boost converter [136]. \\
\hline & & & & 31. & Fig.24. interleaved boost converter with voltage multiplier [137]. \\
\hline & & & & 32. & Fig.25. ZVS interleaved transformer less boost converter [138]. \\
\hline & & & & 33. & Fig.26. Interleaved high step up converter [139]. \\
\hline
\end{tabular}


TABLE III

CHARACTERISTICS LISTED FOR VARIOUS MODIFIED BOOST-BASED TOPOLOGIES

\begin{tabular}{|c|c|c|c|c|c|c|c|c|c|c|c|}
\hline & & & & & & Topology & & & & & \\
\hline Characteristics & 1 & 2 & 3 & 4 & 5 & 6 & 7 & 8 & 9 & 10 & 11 \\
\hline $\begin{array}{l}\text { Voltage stress } \\
\text { across the switch }\end{array}$ & Vo & $\frac{V o}{2}$ & Vo & $\frac{V o}{2}$ & $\frac{V_{O}+V_{i n}}{2}$ & $\frac{V_{O}+V_{i n}}{2}$ & $\frac{V o}{2}$ & $\frac{1}{(1+D)}$ & $\frac{V o}{2}$ & $\frac{1}{(1+D)}$ & $\frac{V i n+1}{\operatorname{Vin}}$ Vo \\
\hline $\begin{array}{l}\text { blocking voltage of } \\
\text { the output diode }\end{array}$ & Vo & $\frac{V o}{2}$ & Vo & - & $\frac{V_{O}+V_{i n}}{2}$ & $\frac{V_{O}+V_{i n}}{2}$ & $\frac{V o}{2}$ & $\frac{1}{(1+D)}$ & $\frac{V o}{2}$ & $\frac{1}{(1+D)}$ & $\frac{\operatorname{Vin}+1}{\operatorname{Vin}} \operatorname{Vo}$ \\
\hline $\begin{array}{l}\text { blocking voltage of } \\
\text { the voltage } \\
\text { multiplier diodes }\end{array}$ & Vo & - & Vo & $\frac{V o}{2}$ & - & - & $\frac{V o}{2}$ & $\frac{1}{(1+D)}$ & $\frac{V o}{2}$ & $\frac{1}{(1+D)}$ & / \\
\hline Voltage gain & $\frac{1}{1-D}$ & $\frac{2}{1-D}$ & $\left(\frac{1}{1-D}\right)^{2}$ & $\frac{1}{2 \cdot(1-D)^{2}}$ & $\frac{1+D}{1-D}$ & $\frac{1+D}{1-D}$ & $\frac{2}{1-D}$ & $-\frac{1+D}{1-D}$ & $\frac{2}{1-D}$ & $-\frac{1+D}{1-D}$ & $\frac{1+3 D}{1-D}$ \\
\hline $\begin{array}{l}\text { Number of } \\
\text { switches }\end{array}$ & 1 & 2 & 1 & 2 & 1 & 2 & 1 & 1 & 1 & 1 & 2 \\
\hline Number of diodes & 1 & 2 & 3 & 4 & 4 & 1 & 3 & 3 & 3 & 3 & 7 \\
\hline $\begin{array}{l}\text { Number of } \\
\text { capacitors }\end{array}$ & 1 & 2 & 2 & 3 & 1 & 1 & 3 & 3 & 3 & 3 & 1 \\
\hline $\begin{array}{l}\text { Number of } \\
\text { inductors }\end{array}$ & 1 & 1 & 2 & 2 & 2 & 2 & 1 & 1 & 1 & 1 & 4 \\
\hline $\begin{array}{l}\text { Number of inductor } \\
\text { cores }\end{array}$ & 1 & 1 & 2 & 2 & 2 & 2 & 1 & 1 & 1 & 1 & 4 \\
\hline Total components & 5 & 8 & 10 & 13 & 10 & 8 & 9 & 9 & 9 & 9 & 18 \\
\hline $\begin{array}{l}\text { Tested switch at } \\
\text { frequency }\end{array}$ & $100 \mathrm{kHz}$ & $\begin{array}{c}100 \\
\mathrm{kHz}\end{array}$ & & $50 \mathrm{kHz}$ & $40 \mathrm{kHz}$ & $\begin{array}{r}100 \\
\mathrm{kHz}\end{array}$ & $\begin{array}{r}100 \\
\mathrm{kHz}\end{array}$ & - & - & - & $100 \mathrm{kHz}$ \\
\hline $\begin{array}{l}\text { Tested input } \\
\text { voltage }\end{array}$ & 35 & & & 34 & $12 \mathrm{~V}$ & $12 \mathrm{~V}$ & $12 \mathrm{~V}$ & - & - & - & $20-40$ \\
\hline $\begin{array}{l}\text { Tested output } \\
\text { voltage }\end{array}$ & $380 \mathrm{~V}$ & & & $380 \mathrm{~V}$ & $\begin{array}{c}60-100 \\
\mathrm{~V}\end{array}$ & $\begin{array}{c}60- \\
100 \mathrm{~V}\end{array}$ & $90 \mathrm{~V}$ & - & - & - & $200 \mathrm{~V}$ \\
\hline $\begin{array}{l}\text { Number of input } \\
\text { sources }\end{array}$ & 1 & & & 1 & 1 & 1 & 1 & - & - & - & 1 \\
\hline $\begin{array}{l}\text { Tested output } \\
\text { power }\end{array}$ & $100 \mathrm{~W}$ & & & $350 \mathrm{~W}$ & $50 \mathrm{~W}$ & $100 \mathrm{~W}$ & $40 \mathrm{~W}$ & - & - & - & $200 \mathrm{~W}$ \\
\hline $\begin{array}{l}\text { Converter } \\
\text { efficiency }\end{array}$ & $85 \%$ & & & $85 \%$ & $91 \%$ & $92 \%$ & $91 \%$ & - & - & - & $91.1 \%$ \\
\hline
\end{tabular}

TABLE IV

CHARACTERISTICS LISTED FOR VARIOUS MODIFIED BOOST-BASED DC-DC CONVERTERS Topology

\begin{tabular}{|c|c|c|c|c|c|c|c|c|c|c|c|}
\hline Characteristics & 12 & 13 & 14 & 15 & 16 & 17 & 18 & 19 & 20 & 21 & 22 \\
\hline \multirow{2}{*}{$\begin{array}{l}\text { Voltage stress } \\
\text { across the switch }\end{array}$} & $V o+V i n$ & Vo & Vin & 1 & Vo & 1 & 1 & $V o+V i$ & 1 & 1 & 1 \\
\hline & 4 & & $\overline{(1-D)}$ & $\overline{3-D}$ & 2 & $\overline{3}$ & $\overline{3}$ & 2 & $\overline{3}$ & $\overline{3}$ & $\overline{3-D}$ \\
\hline \multirow{2}{*}{$\begin{array}{l}\text { blocking voltage of } \\
\text { the output diode }\end{array}$} & / & Vo & Vin & 1 & - & 1 & - & 2.Vo & - & - & - \\
\hline & & & $\overline{(1-D)}$ & $\overline{3-D}$ & & $\overline{3}$ & & & & & \\
\hline \multirow{4}{*}{$\begin{array}{l}\text { blocking voltage of } \\
\text { the voltage } \\
\text { multiplier diodes }\end{array}$} & $V o+V i n$ & - & Vin1 & 1 & Vo & 1 & 1 & - & 1 & 1 & Vin \\
\hline & 2 & & $\overline{(1-D)}$ & $\overline{3-D}$ & 2 & $\overline{3}$ & $\overline{3}$ & & $\overline{3}$ & $\overline{3}$ & $\overline{(1-d)}$ \\
\hline & & & $+\operatorname{Vin} 2$ & & & & & & & & \\
\hline & & & $+\overline{(1-D)}$ & & & & & & & & \\
\hline \multirow[t]{4}{*}{ Voltage gain } & $3+5 D$ & $(1)^{N}$ & $N+1 \quad 1$ & $3-D$ & 2 & 3 & 3 & $(1+D)$ & $2+(N-1) L$ & $1+N D$ & $3-D$ \\
\hline & $\overline{1-D}$ & $(\overline{1-D})$ & $\overline{2} \cdot \overline{(1-D)}$ & $\overline{1-D}$ & $\overline{1-D}$ & $\overline{1-D}$ & $\overline{1-D}$ & $\overline{(1-D)}$ & $1-D$ & $1-D$ & $\overline{(1-D)}$ \\
\hline & & & $N+1$ & & & & & & & & \\
\hline & & & $\overline{2} \cdot \overline{(1-D)}$ & & & & & & & & \\
\hline
\end{tabular}




\begin{tabular}{|c|c|c|c|c|c|c|c|c|c|c|c|}
\hline $\begin{array}{l}\text { Number of } \\
\text { switches }\end{array}$ & 2 & 2 & 2 & 1 & 1 & 1 & 1 & 2 & 1 & 1 & 1 \\
\hline Number of diodes & 9 & 2 & 4 & 4 & 3 & 5 & 5 & 1 & 4 & 4 & 4 \\
\hline $\begin{array}{l}\text { Number of } \\
\text { capacitors }\end{array}$ & 3 & 2 & 4 & 4 & 3 & 5 & 5 & 1 & 5 & 5 & 4 \\
\hline $\begin{array}{l}\text { Number of } \\
\text { inductors }\end{array}$ & 4 & 2 & 2 & 1 & 1 & 1 & 1 & 2 & 2 & 2 & 1 \\
\hline $\begin{array}{l}\text { Number of inductor } \\
\text { cores }\end{array}$ & 4 & 2 & 2 & 1 & 1 & 1 & 1 & 1 & 2 & 2 & 1 \\
\hline Total components & 22 & 10 & 14 & 11 & 9 & 13 & 13 & 7 & 14 & 14 & 11 \\
\hline $\begin{array}{l}\text { Tested switch at } \\
\text { frequency }\end{array}$ & $100 \mathrm{kHz}$ & $100 \mathrm{kHz}$ & $100 \mathrm{kHz}$ & $\begin{array}{r}100 \\
\mathrm{kHz}\end{array}$ & $\begin{array}{c}50 \\
\mathrm{kHz}\end{array}$ & - & $75 \mathrm{kHz}$ & $100 \mathrm{kHz}$ & $10 \mathrm{kHz}$ & - & $40 \mathrm{kHz}$ \\
\hline $\begin{array}{l}\text { Tested input } \\
\text { voltage }\end{array}$ & $20-40$ & $120 \mathrm{~V}$ & $20 \mathrm{~V}$ & $\begin{array}{c}66-190 \\
\mathrm{~V}\end{array}$ & $12 \mathrm{~V}$ & - & $12 \mathrm{~V}$ & $12 \mathrm{~V}$ & $25-36-45 \mathrm{~V}$ & - & \\
\hline $\begin{array}{l}\text { Tested output } \\
\text { voltage }\end{array}$ & $400 \mathrm{~V}$ & $400 \mathrm{~V}$ & $400 \mathrm{~V}$ & $660 \mathrm{~V}$ & $80 \mathrm{~V}$ & - & $110 \mathrm{~V}$ & $60-100 \mathrm{~V}$ & $380 \mathrm{~V}$ & - & $380 \mathrm{~V}$ \\
\hline $\begin{array}{l}\text { Number of input } \\
\text { sources }\end{array}$ & 1 & 1 & 2 & 1 & 1 & - & 1 & 1 & 1 & - & 1 \\
\hline $\begin{array}{l}\text { Tested output } \\
\text { power }\end{array}$ & $200 \mathrm{~W}$ & $300 \mathrm{~W}$ & $400 \mathrm{~W}$ & $15 \mathrm{~W}$ & - & - & - & $40 \mathrm{~W}$ & $40 \mathrm{~W}$ & - & $240 \mathrm{~W}$ \\
\hline $\begin{array}{l}\text { Converter } \\
\text { efficiency }\end{array}$ & $91.8 \%$ & $85 \%$ & $91.4 \%$ & $78 \%$ & - & - & - & $91 \%$ & $96 \%$ & - & $94.44 \%$ \\
\hline
\end{tabular}

TABLE V

CHARACTERISTICS LISTED FOR VARIOUS MODIFIED BOOST-BASED DC-DC CONVERTERS Topology

\begin{tabular}{|c|c|c|c|c|c|c|c|c|c|c|c|}
\hline Characteristics & 23 & 24 & 25 & 26 & 27 & 28 & 29 & 30 & 31 & 32 & 33 \\
\hline $\begin{array}{l}\text { Voltage stress } \\
\text { across the switch }\end{array}$ & $\frac{1}{3}$ & $\frac{V o}{N+1}$ & $\frac{V o}{2(N+1)}$ & $\begin{array}{l}\frac{1}{1-D} \\
+\frac{D(N-1)}{2(1-D)}\end{array}$ & $\frac{V o}{N(2+d)+3}$ & $\frac{V o}{2(N+1)}$ & $\frac{V o}{2(2 N+3)}$ & Vo & $\frac{V o}{2(N+1)}$ & $\frac{V o}{2(N+1)}$ & $\frac{V o}{2(N+1)}$ \\
\hline $\begin{array}{l}\text { blocking voltage of } \\
\text { the output diode }\end{array}$ & $\frac{1}{3}$ & Vo & $\frac{V o}{2}$ & $\begin{array}{l}\frac{1}{1-D} \\
+\frac{D(N-1)}{2(1-D)}\end{array}$ & $\frac{(N+1) V o}{N(2+D)+3}$ & - & - & Vo & - & Vo & - \\
\hline $\begin{array}{l}\text { blocking voltage of } \\
\text { the voltage } \\
\text { multiplier diodes }\end{array}$ & - & - & - & $\begin{array}{l}\frac{1}{1-D} \\
+\frac{D(N-1)}{2(1-D)}\end{array}$ & - & $\frac{N \cdot V o}{(N+1)}$ & $\frac{(2 N+1)}{(2 N+3)} V_{o}$ & - & $\frac{N \cdot V o}{(N+1)}$ & $\frac{\text { Vin }}{(1-D)}$ & $\frac{2 . N+1}{2(N+1)}$ \\
\hline Voltage gain & $\frac{N D+1}{1-D}$ & $\frac{N-1}{1-D}$ & $\frac{2(1+N)}{(1-D)}$ & $\frac{2+N}{1-D}+N$ & $\frac{N(2+D)+3}{(1-D)}$ & $\frac{2(N+1)}{(1-D)}$ & $\frac{(2 N+3)}{(1-D)}$ & $\frac{1}{1-D}$ & $\frac{2(N+1)}{(1-D)}$ & $\begin{array}{c}\frac{4(N+1)}{(1-D)+\sqrt{(1-L}} \\
\text { Where; } Q= \\
\text { 16. } f s . L k / R o\end{array}$ & $\frac{2(N+1)}{(1-D)}$ \\
\hline $\begin{array}{l}\text { Number of } \\
\text { switches }\end{array}$ & 2 & 2 & 2 & 1 & 1 & 2 & 2 & 2 & 2 & 4 & 2 \\
\hline Number of diodes & 1 & 2 & 4 & 4 & 5 & 4 & 4 & 2 & 6 & 2 & 6 \\
\hline $\begin{array}{l}\text { Number of } \\
\text { capacitors }\end{array}$ & 1 & 1 & 4 & 4 & 5 & 4 & 4 & 1 & 5 & 5 & 5 \\
\hline $\begin{array}{l}\text { Number of } \\
\text { inductors }\end{array}$ & 3 & 2 & 2 & 3 & 2 & 2 & 2 & 2 & 2 & 4 & 2 \\
\hline $\begin{array}{l}\text { Number of inductor } \\
\text { cores }\end{array}$ & 3 & 1 & 1 & 2 & 1 & 2 & 2 & 2 & 2 & 2 & 4 \\
\hline Total components & 10 & 8 & 13 & 14 & 14 & 14 & 14 & 9 & 17 & 17 & 19 \\
\hline $\begin{array}{l}\text { Tested switch(es) at } \\
\text { frequency }\end{array}$ & $\begin{array}{c}50 \\
\mathrm{kHz}\end{array}$ & $\begin{array}{r}100 \\
\mathrm{kHz}\end{array}$ & $100 \mathrm{kHz}$ & $50 \mathrm{kHz}$ & $50 \mathrm{kHz}$ & $40 \mathrm{kHz}$ & $50 \mathrm{kHz}$ & $\begin{array}{r}100 \\
\mathrm{kHz}\end{array}$ & $40 \mathrm{kHz}$ & $50 \mathrm{kHz}$ & $50 \mathrm{kHz}$ \\
\hline $\begin{array}{l}\text { Tested input } \\
\text { voltage }\end{array}$ & $\begin{array}{c}25-40 \\
\mathrm{~V}\end{array}$ & $\begin{array}{c}40- \\
56 \mathrm{~V}\end{array}$ & $40-56 \mathrm{~V}$ & $24 \mathrm{~V}$ & $24 \mathrm{~V}$ & $18-36 \mathrm{~V}$ & $16-22 \mathrm{~V}$ & $40 \mathrm{~V}$ & $40 \mathrm{~V}$ & $12-14 \mathrm{~V}$ & $30-45 \mathrm{~V}$ \\
\hline
\end{tabular}




\begin{tabular}{|c|c|c|c|c|c|c|c|c|c|c|c|}
\hline $\begin{array}{l}\text { Tested output } \\
\text { voltage }\end{array}$ & $200 \mathrm{~V}$ & $\begin{array}{c}380 \\
\mathrm{~V}\end{array}$ & $380 \mathrm{~V}$ & $400 \mathrm{~V}$ & $400 \mathrm{~V}$ & $200 \mathrm{~V}$ & $200 \mathrm{~V}$ & $\begin{array}{c}380 \\
\mathrm{~V}\end{array}$ & $380 \mathrm{~V}$ & $120 \mathrm{~V}$ & $380 \mathrm{~V}$ \\
\hline $\begin{array}{l}\text { Number of input } \\
\text { sources }\end{array}$ & 1 & 1 & 1 & 1 & 1 & 1 & 1 & 1 & 1 & 1 & 1 \\
\hline $\begin{array}{l}\text { Tested output } \\
\text { power }\end{array}$ & $\begin{array}{c}100 \\
\mathrm{~W} \\
\end{array}$ & $\begin{array}{c}500 \\
W\end{array}$ & $500 \mathrm{~W}$ & $200 \mathrm{~W}$ & $\begin{array}{c}100 \mathrm{~W}, 300 \\
\mathrm{~W}\end{array}$ & $200 \mathrm{~W}$ & $400 \mathrm{~W}$ & $\begin{array}{c}500 \\
W \\
\end{array}$ & $\begin{array}{c}400 \mathrm{~W}- \\
1 \mathrm{~kW}\end{array}$ & $150 \mathrm{~W}, 500 \mathrm{~W}$ & $1 \mathrm{~kW}$ \\
\hline $\begin{array}{l}\text { Converter } \\
\text { efficiency }\end{array}$ & $\begin{array}{c}94.4 \\
\%\end{array}$ & $\begin{array}{c}96.4 \\
\%\end{array}$ & $96.9 \%$ & $95.7 \%$ & $\begin{array}{c}95.4 \%, 93.9 \\
\%\end{array}$ & $94.37 \%$ & - & $85 \%$ & $\begin{array}{c}97.1 \%- \\
96.4 \%\end{array}$ & $96.8 \%, 91.2 \%$ & $95.1 \%$ \\
\hline
\end{tabular}

It is tricky to give a comparative analysis of the performance of each topology simply based on the level of its voltage gain curve, particularly with different number of component count for different topologies. In most of these topologies. Higher voltage gain values can be attained either by increasing turns ratio of interleaved inductor topologies and coupled or by including more number of components. The demerits include higher cost, complexity and bulkiness of converter topologies. As $S C$ cell-based topologies in Table IV at the cost of higher component count can achieve a higher voltage gain against the basic boost. Also, the coupled and interleaved inductor-based topologies in Table III and Table V can attain higher gain by high turns ratio which in response will increase its leakage inductance. As a result of this analysis, selection of the topology for application of micro PV inverters, uninterruptible power supplies, fuel cell and etc, must be made after looking at elements involved and attained voltage ratio. After achieving a higher voltage gain the output diode and switch voltage stress is a crucial factor as the overall cost of the system can increase by employing higher rated components. Furthermore, voltage stress on semiconductor components is evaluated. This can offer a two times higher voltage gain against the basic boost converter with 3-level and cascaded boost converter modifications, but the power losses are also doubled as these topologies involve two switches. Moreover, cascaded boost converters confronts the problem of equivalent switch stress and output voltage. Application with low voltage variation, $S C$ cell-based boost converters with fixed voltage gain can be employed, which have simpler structure and higher efficiency. If a comparatively high voltage gain is required, the converters from $S C$-cell based boost converters with $n$ times voltage gain can be utilized at the expense of additional components. In advantage the switches and diodes voltage stresses is reduced higher than one-half of voltage at the output. Therefore, overall cost of the system and switching losses can be subsided by utilizing lower voltage rated power devices with low

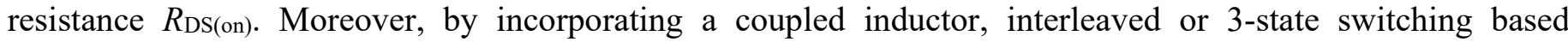
converters higher voltage gain can be attained. As a commendable merit these converters allow current sharing. However, voltage ringing is often resulted due to resonance between intrinsic capacitance and leakage inductance of active switch, which leads to poor efficiency. In addition, leakage inductance has the ability to compensate the falling current rates of diodes. Nullifying the diode reverse-recovery issues. Moreover, voltage stresses on the switch is one third of the output voltage and leakage-inductor energy is available to be reprocessed at the output. Table VI presents the modification techniques used in the basic boost converter.

TABLE VI

MODIFICATION TECHNIQUES USED IN THE BOOST-BASED DC-DC CONVERTER TOPOLOGIES

\begin{tabular}{|c|c|c|c|c|c|c|c|c|c|c|c|}
\hline \multirow[t]{2}{*}{ \# } & \multirow[t]{2}{*}{ Topology } & \multicolumn{10}{|c|}{ Modification techniques used } \\
\hline & & $\begin{array}{c}\text { Non- } \\
\text { extendable } \\
\text { voltage gain }\end{array}$ & $\begin{array}{c}\text { Extendable } \\
\text { voltage gain }\end{array}$ & $\begin{array}{l}S C- \\
\text { Cell }\end{array}$ & $\begin{array}{l}\text { SI- } \\
\text { Cell }\end{array}$ & $\begin{array}{l}\text { Interleaved } \\
\text { inductor }\end{array}$ & $\begin{array}{l}\text { Coupled } \\
\text { inductor }\end{array}$ & Multiport & Cascaded & SS3 & $\begin{array}{l}\text { Active } \\
\text { network }\end{array}$ \\
\hline 1. & Fig. 1. (a) & - & - & - & - & - & - & - & - & - & - \\
\hline 2. & Fig.5. (a) & yes & - & - & - & - & - & - & - & - & - \\
\hline
\end{tabular}




\begin{tabular}{|c|c|c|c|c|c|c|c|c|c|c|c|}
\hline 3. & Fig.5. (b) & yes & - & - & - & - & - & - & - & - & - \\
\hline 4. & Fig.5. (c) & yes & - & - & - & - & - & - & - & - & - \\
\hline 5. & Fig.6. (a) & yes & - & - & yes & - & - & - & - & - & - \\
\hline 6. & Fig.6. (b) & yes & - & - & yes & - & - & - & - & - & - \\
\hline 7. & Fig.8. (a) & yes & - & yes & - & - & - & - & - & - & - \\
\hline 8. & Fig.8. (b) & yes & - & yes & - & - & - & - & - & - & - \\
\hline 9. & Fig.8. (c) & yes & - & yes & - & - & - & - & - & - & - \\
\hline 10. & Fig.8. (d) & yes & - & yes & - & - & - & - & - & - & - \\
\hline 11. & Fig.9. (a) & yes & - & - & yes & - & - & - & - & - & yes \\
\hline 12. & Fig.9. (b) & yes & - & - & yes & - & - & - & - & - & yes \\
\hline 13. & Fig.9. (c) & - & yes & yes & yes & - & - & - & - & - & - \\
\hline 14. & Fig.10. & - & yes & - & - & - & - & - & yes & - & - \\
\hline 15. & Fig.11. & - & yes & yes & - & - & - & yes & - & - & - \\
\hline 16. & Fig.12. (a) & - & yes & yes & - & - & - & - & - & - & - \\
\hline 17. & Fig.12. (b) & - & yes & yes & - & - & - & - & - & - & - \\
\hline 18. & Fig.13. (a) & - & yes & yes & - & - & - & - & - & - & - \\
\hline 19. & Fig.13. (b) & - & yes & yes & - & - & - & - & - & - & - \\
\hline 20. & Fig.14. (a) & - & yes & yes & - & - & - & - & - & - & - \\
\hline 21. & Fig.14. (b) & - & yes & yes & - & - & - & - & - & - & - \\
\hline 22. & Fig.15. & - & yes & yes & - & - & - & - & - & - & - \\
\hline 23. & Fig.16. & - & yes & & - & - & yes & - & - & - & - \\
\hline 24. & Fig.17. & - & yes & yes & - & - & yes & - & - & - & - \\
\hline 25. & Fig.18. & - & yes & yes & - & - & yes & - & - & - & - \\
\hline 26. & Fig.19. & - & yes & yes & - & - & yes & - & - & - & - \\
\hline 27. & Fig.20. & - & yes & yes & - & - & yes & - & - & - & - \\
\hline 28. & Fig.21. & - & yes & yes & - & - & yes & - & - & - & - \\
\hline 29. & Fig.22. & - & yes & yes & - & - & - & - & - & yes & - \\
\hline 30. & Fig.23. & - & yes & & - & yes & - & - & - & - & - \\
\hline 31. & Fig.24. & - & yes & yes & - & yes & - & - & - & - & - \\
\hline 32. & Fig. 25. & - & yes & yes & - & yes & - & - & - & - & - \\
\hline 33. & Fig.26. & - & yes & yes & - & yes & - & - & - & - & - \\
\hline
\end{tabular}




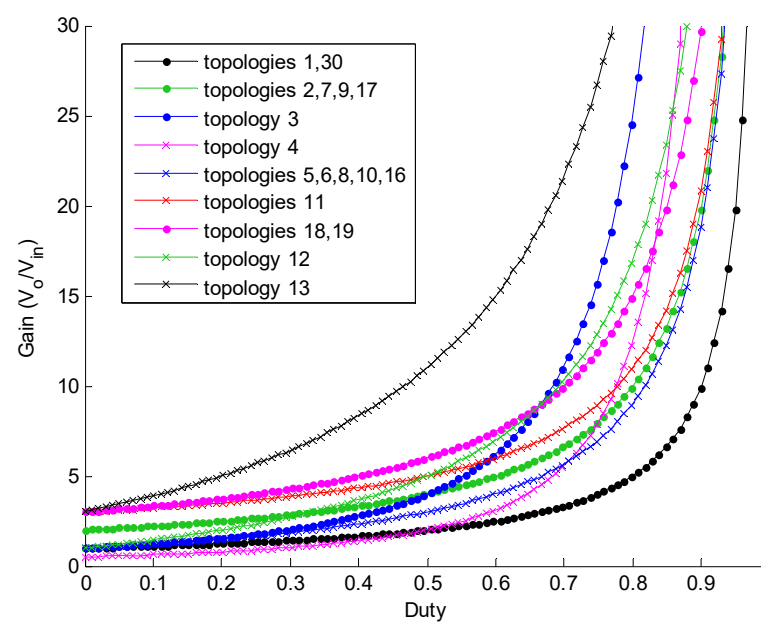

(a)

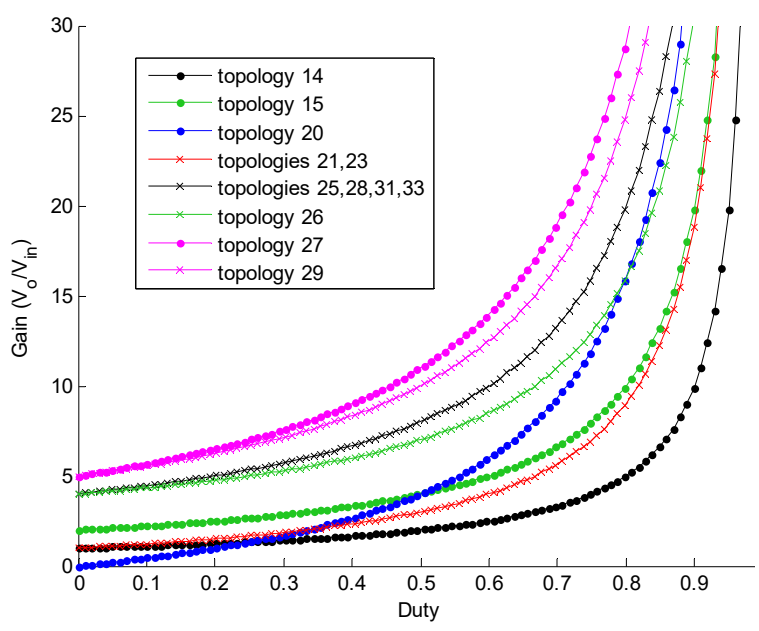

(b)

Fig. 27. (a) topologies with voltage gains (b) topologies with (n) times voltage gains.

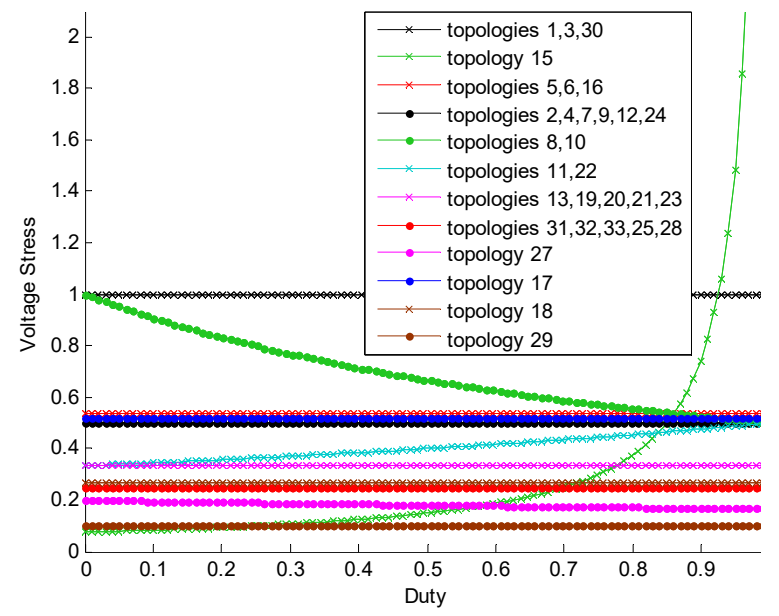

Fig. 28. Voltage stress on switch(es).

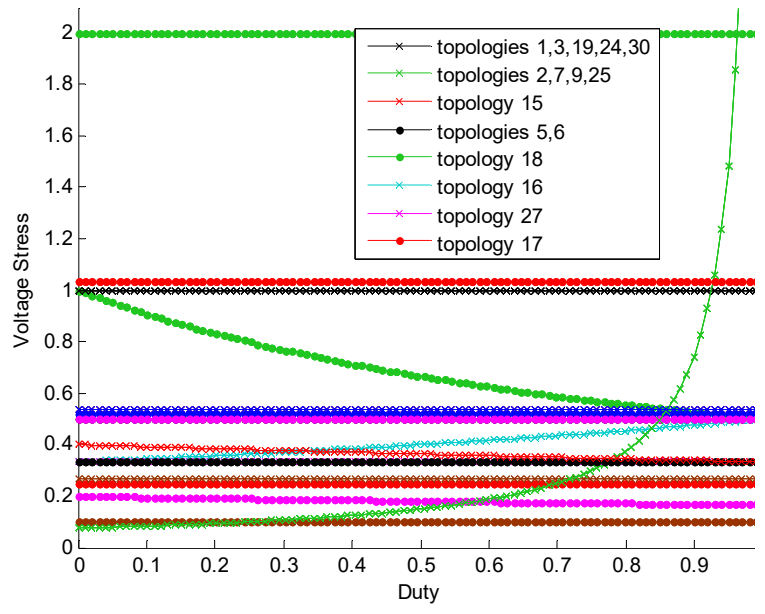

Fig. 29. Voltage stress on output diode.

\section{Conclusion}

The output voltage on conventional boost converter can only be stepped up by increasing the on time of the semiconductor components. Additionally, if on time of the switch is increased more than $90 \%$; the power losses amplify, which will lead to efficiency degradation. In light of the aforementioned problem, this paper presents a comparative analysis on wide range of topologies based on the structure of conventional boost converter. Moreover, the topologies are categorized 
under their ability to provide fixed or $n$ times voltage gain, additionally; topologies are compared based on the switch on time versus the voltage gain.

\section{Acknowledgement}

The authors thank the technical and financial assistance of UM Power Energy Dedicated Advanced Centre (UMPEDAC) and the Higher Institution Centre of Excellence (HICoE) Program Research Grant, UMPEDAC - 2016 (MOHE HICOE - UMPEDAC). As well as the project funding from the Malaysian Ministry of Higher Education undergrant MO013-2016 (Investigation on The Next Generation Renewable Energy Generators Based on M.O.R.E Intelligent Power Electronics Converters).

\section{References}

[1] R. Hasan and S. Mekhilef, "Highly efficient flyback microinverter for grid-connected rooftop PV system," Solar Energy, vol. 146, pp. 511-522, 2017/04/01/ 2017.

[2] A. S. Mundada, Y. Nilsiam, and J. M. Pearce, "A review of technical requirements for plug-and-play solar photovoltaic microinverter systems in the United States," Solar Energy, vol. 135, pp. 455-470, 2016/10/01/ 2016.

[3] N. U. Day, C. C. Reinhart, S. DeBow, M. K. Smith, D. J. Sailor, E. Johansson, et al., "Thermal effects of microinverter placement on the performance of silicon photovoltaics," Solar Energy, vol. 125, pp. 444-452, 2016/02/01/ 2016.

[4] W.-J. Cha, J.-M. Kwon, and B.-H. Kwon, "Highly efficient step-up dc-dc converter for photovoltaic microinverter," Solar Energy, vol. 135, pp. 14-21, 2016/10/01/ 2016.

[5] C. L. Trujillo, F. Santamaría, and E. E. Gaona, "Modeling and testing of two-stage grid-connected photovoltaic micro-inverters," Renewable Energy, vol. 99, pp. 533-542, 2016/12/01/ 2016.

[6] H. Zheng, S. Li, R. Challoo, and J. Proano, "Shading and bypass diode impacts to energy extraction of PV arrays under different converter configurations," Renewable Energy, vol. 68, pp. 58-66, 2014/08/01/ 2014.

[7] M. Ashari, C. V. Nayar, and W. W. L. Keerthipala, "Optimum operation strategy and economic analysis of a photovoltaic-diesel-battery-mains hybrid uninterruptible power supply," Renewable Energy, vol. 22, pp. 247-254, 2001/01/01/2001.

[8] J. M. Andújar, F. Segura, E. Durán, and L. A. Rentería, "Optimal interface based on power electronics in distributed generation systems for fuel cells," Renewable Energy, vol. 36, pp. 2759-2770, 2011/11/01/ 2011.

[9] Q. Zhao, F. Tao, Y. Hu, and F. C. Lee, "Active-clamp DC/DC converters using magnetic switches," in Applied Power Electronics Conference and Exposition, 2001. APEC 2001. Sixteenth Annual IEEE, 2001, pp. 946-952.

[10] M. Prudente, L. L. Pfitscher, G. Emmendoerfer, E. F. Romaneli, and R. Gules, "Voltage multiplier cells applied to non-isolated DC-DC converters," IEEE Transactions on Power Electronics, vol. 23, pp. 871$887,2008$.

[11] K.-B. Park, H.-W. Seong, H.-S. Kim, G.-W. Moon, and M.-J. Youn, "Integrated boost-sepic converter for high step-up applications," in 2008 IEEE Power Electronics Specialists Conference, 2008, pp. 944-950.

[12] R.-J. Wai and R.-Y. Duan, "High step-up converter with coupled-inductor," IEEE Transactions on Power Electronics, vol. 20, pp. 1025-1035, 2005.

[13] E. J. Copple, "High efficiency DC step-up voltage converter," ed: Google Patents, 1999.

[14] J. Yaghoobi, M. Islam, and N. Mithulananthan, "Analytical approach to assess the loadability of unbalanced distribution grid with rooftop PV units," Applied Energy, vol. 211, pp. 358-367, 2018/02/01/ 2018.

[15] G. Zubi, R. Dufo-López, G. Pasaoglu, and N. Pardo, "Techno-economic assessment of an off-grid PV system for developing regions to provide electricity for basic domestic needs: A 2020-2040 scenario," Applied Energy, vol. 176, pp. 309-319, 2016/08/15/ 2016.

[16] S. Saravanan and N. Ramesh Babu, "Analysis and implementation of high step-up DC-DC converter for PV based grid application," Applied Energy, vol. 190, pp. 64-72, 2017/03/15/2017. 
[17] J. C. Solano, L. Olivieri, and E. Caamaño-Martín, "Assessing the potential of PV hybrid systems to cover HVAC loads in a grid-connected residential building through intelligent control," Applied Energy, vol. 206, pp. 249-266, 2017/11/15/2017.

[18] S. R. Madeti and S. N. Singh, "Online modular level fault detection algorithm for grid-tied and off-grid PV systems," Solar Energy, vol. 157, pp. 349-364, 2017/11/15/2017.

[19] A. Q. Al-Shetwi, M. Z. Sujod, and F. Blaabjerg, "Low voltage ride-through capability control for singlestage inverter-based grid-connected photovoltaic power plant," Solar Energy, vol. 159, pp. 665-681, 2018/01/01/2018.

[20] A. Darwish, A. M. Massoud, D. Holliday, S. Ahmed, and B. Williams, "Single-stage Three-phase Differential-mode Buck-Boost Inverters with Continuous Input Current for PV Applications," IEEE Transactions on Power Electronics, vol. 31, pp. 8218-8236, 2016.

[21] K. M. Tsang and W. L. Chan, "A single switch DC/DC converter with galvanic isolation and input current regulation for photovoltaic systems," Solar Energy, vol. 119, pp. 203-211, 2015/09/01/ 2015.

[22] G. Chu, H. Wen, L. Jiang, Y. Hu, and X. Li, "Bidirectional flyback based isolated-port submodule differential power processing optimizer for photovoltaic applications," Solar Energy, vol. 158, pp. 929-940, 2017/12/01/ 2017.

[23] H.-s. Kim, J.-H. Kim, B.-D. Min, D.-W. Yoo, and H.-J. Kim, "A highly efficient PV system using a series connection of DC-DC converter output with a photovoltaic panel," Renewable Energy, vol. 34, pp. 24322436, 2009/11/01/ 2009.

[24] V. Azbe and R. Mihalic, "Distributed generation from renewable sources in an isolated DC network," Renewable Energy, vol. 31, pp. 2370-2384, 2006/11/01/ 2006.

[25] N. H. Saad, A. A. El-Sattar, and A. E.-A. M. Mansour, "Improved particle swarm optimization for photovoltaic system connected to the grid with low voltage ride through capability," Renewable Energy, vol. 85, pp. 181-194, 2016/01/01/2016.

[26] J. A. Baroudi, V. Dinavahi, and A. M. Knight, "A review of power converter topologies for wind generators," Renewable Energy, vol. 32, pp. 2369-2385, 2007/11/01/2007.

[27] S. Iqbal, G. K. Singh, and R. Besar, "A dual-mode input voltage modulation control scheme for voltage multiplier based X-ray power supply," IEEE Transactions on Power Electronics, vol. 23, pp. 1003-1008, 2008.

[28] D. Zhou, A. Pietkiewicz, and S. Cuk, "A three-switch high-voltage converter," IEEE Transactions on Power Electronics, vol. 14, pp. 177-183, 1999.

[29] J. Sun, X. Ding, M. Nakaoka, and H. Takano, "Series resonant ZCS-PFM DC-DC converter with multistage rectified voltage multiplier and dual-mode PFM control scheme for medical-use high-voltage Xray power generator," IEE Proceedings-Electric Power Applications, vol. 147, pp. 527-534, 2000.

[30] A. Amir, H. S. Che, A. Amir, A. El Khateb, and N. A. Rahim, "Transformerless high gain boost and buckboost DC-DC converters based on extendable switched capacitor (SC) cell for stand-alone photovoltaic system," Solar Energy, vol. 171, pp. 212-222, 2018/09/01/2018.

[31] Z. Chen, S. Liu, and L. Shi, "A soft switching full bridge converter with reduced parasitic oscillation in a wide load range," Power Electronics, IEEE Transactions on, vol. 29, pp. 801-811, 2014.

[32] W. Li and X. He, "Review of nonisolated high-step-up DC/DC converters in photovoltaic grid-connected applications," IEEE Transactions on Industrial Electronics, vol. 58, pp. 1239-1250, 2011.

[33] F. L. Tofoli, D. de Castro Pereira, W. J. de Paula, and D. d. S. O. Júnior, "Survey on non-isolated highvoltage step-up dc-dc topologies based on the boost converter," IET Power Electronics, vol. 8, pp. 20442057, 2015.

[34] F. Wang, "A novel quadratic Boost converter with low current and voltage stress on power switch for fuelcell system applications," Renewable Energy, vol. 115, pp. 836-845, 2018/01/01/ 2018.

[35] M. A. Al-Saffar and E. H. Ismail, "A high voltage ratio and low stress DC-DC converter with reduced input current ripple for fuel cell source," Renewable Energy, vol. 82, pp. 35-43, 2015/10/01/ 2015.

[36] P. M. García-Vite, C. A. Soriano-Rangel, J. C. Rosas-Caro, and F. Mancilla-David, "A DC-DC converter with quadratic gain and input current ripple cancelation at a selectable duty cycle," Renewable Energy, vol. 101, pp. 431-436, 2017/02/01/2017.

[37] N. Mohan and T. M. Undeland, Power electronics: converters, applications, and design: John Wiley \& Sons, 2007.

[38] R. W. Erickson and D. Maksimovic, Fundamentals of power electronics: Springer Science \& Business Media, 2007. 
[39] F.-s. Kang, S.-J. Park, S. E. Cho, and J.-M. Kim, "Photovoltaic power interface circuit incorporated with a buck-boost converter and a full-bridge inverter," Applied Energy, vol. 82, pp. 266-283, 2005/11/01/ 2005.

[40] M. Farhat, O. Barambones, and L. Sbita, "A new maximum power point method based on a sliding mode approach for solar energy harvesting," Applied Energy, vol. 185, pp. 1185-1198, 2017/01/01/ 2017.

[41] G. Graditi, G. Adinolfi, and G. M. Tina, "Photovoltaic optimizer boost converters: Temperature influence and electro-thermal design," Applied Energy, vol. 115, pp. 140-150, 2014/02/15/2014.

[42] R. Ayop and C. W. Tan, "Design of boost converter based on maximum power point resistance for photovoltaic applications," Solar Energy, vol. 160, pp. 322-335, 2018/01/15/ 2018.

[43] D. D. C. Lu and Q. N. Nguyen, "A photovoltaic panel emulator using a buck-boost DC/DC converter and a low cost micro-controller," Solar Energy, vol. 86, pp. 1477-1484, 2012/05/01/ 2012.

[44] D. Guilbert, A. Gaillard, A. N'Diaye, and A. Djerdir, "Power switch failures tolerance and remedial strategies of a 4-leg floating interleaved DC/DC boost converter for photovoltaic/fuel cell applications," Renewable Energy, vol. 90, pp. 14-27, 2016/05/01/2016.

[45] S. Li, A. Attou, Y. Yang, and D. Geng, "A maximum power point tracking control strategy with variable weather parameters for photovoltaic systems with DC bus," Renewable Energy, vol. 74, pp. 478-488, 2015/02/01/2015.

[46] M. A. Al-Saffar, E. H. Ismail, and A. J. Sabzali, "Family of ZC-ZVS converters with wide voltage range for renewable energy systems," Renewable Energy, vol. 56, pp. 32-43, 2013/08/01/ 2013.

[47] S. Chiang, H.-J. Shieh, and M.-C. Chen, "Modeling and control of PV charger system with SEPIC converter," IEEE Transactions on Industrial Electronics, vol. 56, pp. 4344-4353, 2009.

[48] B. W. Williams, "DC-to-DC converters with continuous input and output power," IEEE Transactions on Power Electronics, vol. 28, pp. 2307-2316, 2013.

[49] A. H. El Khateb, N. A. Rahim, J. Selvaraj, and B. W. Williams, "DC-to-DC converter with low input current ripple for maximum photovoltaic power extraction," IEEE Transactions on Industrial Electronics, vol. 62, pp. 2246-2256, 2015.

[50] V. Fernão Pires, D. Foito, F. R. B. Baptista, and J. Fernando Silva, "A photovoltaic generator system with a DC/DC converter based on an integrated Boost-Ćuk topology," Solar Energy, vol. 136, pp. 1-9, 2016/10/15/2016.

[51] W.-Y. Choi, "Three-level single-ended primary-inductor converter for photovoltaic power conditioning systems," Solar Energy, vol. 125, pp. 43-50, 2016/02/01/ 2016.

[52] A. J. Sabzali, E. H. Ismail, and H. M. Behbehani, "High voltage step-up integrated double Boost-Sepic DC-DC converter for fuel-cell and photovoltaic applications," Renewable Energy, vol. 82, pp. 44-53, 2015/10/01/2015.

[53] J. P. M. Figueiredo, F. L. Tofoli, and R. L. Alves, "Comparison of nonisolated dc-dc converters from the efficiency point of view," in XI Brazilian Power Electronics Conference, 2011, pp. 14-19.

[54] M. Umamaheswari, G. Uma, and K. Vijayalakshmi, "Design and implementation of reduced-order sliding mode controller for higher-order power factor correction converters," IET power electronics, vol. 4, pp. 984-992, 2011.

[55] A. A. Fardoun, E. H. Ismail, A. J. Sabzali, and M. A. Al-Saffar, "New efficient bridgeless Cuk rectifiers for PFC applications," IEEE transactions on power electronics, vol. 27, pp. 3292-3301, 2012.

[56] H. Ma, J.-S. Lai, Q. Feng, W. Yu, C. Zheng, and Z. Zhao, "A novel valley-fill SEPIC-derived power supply without electrolytic capacitor for LED lighting application," IEEE Transactions on Power Electronics, vol. 27, pp. 3057-3071, 2012.

[57] H.-L. Do, "Soft-switching SEPIC converter with ripple-free input current," IEEE Transactions on Power Electronics, vol. 27, pp. 2879-2887, 2012.

[58] Z. Chen, "PI and sliding mode control of a Cuk converter," IEEE Transactions on Power Electronics, vol. 27, pp. 3695-3703, 2012.

[59] C. Don Li, "A SEPIC Fed Buck Converter."

[60] W. Li and X. He, "ZVT interleaved boost converters for high-efficiency, high step-up DC-DC conversion," IET Electric Power Applications, vol. 1, pp. 284-290, 2007.

[61] R.-J. Wai, C.-Y. Lin, R.-Y. Duan, and Y.-R. Chang, "High-efficiency DC-DC converter with high voltage gain and reduced switch stress," IEEE Transactions on Industrial Electronics, vol. 54, pp. 354-364, 2007.

[62] K.-C. Tseng, C.-C. Huang, and C.-A. Cheng, "A Single-Switch Converter with High Step-up Gain and Low Diode Voltage Stress Suitable for Green Power-Source Conversion," 2015.

[63] K. M. Smith and K. M. Smedley, "Properties and synthesis of passive lossless soft-switching PWM converters," IEEE transactions on power electronics, vol. 14, pp. 890-899, 1999. 
[64] C. A. Canesin, F. A. Goncalves, E. Leandro, and J. O. Pinto, "A Novel HPF Voltage Source Rectifier for Variable Speed Refrigeration Systems," in 2006 IEEE International Symposium on Industrial Electronics, 2006, pp. 1414-1419.

[65] M. Nakamura, K. Ogura, and M. Nakaoka, "Soft-switching PWM boost chopper-fed DC-DC power converter with load side auxiliary passive resonant snubber," Journal of Power Electronics, vol. 4, pp. 161168, 2004.

[66] M. Asha and J. Mathew, "Non isolated Boost converters with Switched Inductor Technique," in Signal Processing, Communication, Computing and Networking Technologies (ICSCCN), 2011 International Conference on, 2011, pp. 757-761.

[67] Y. Yu, G. Konstantinou, C. D. Townsend, R. P. Aguilera, and V. G. Agelidis, "Delta-Connected Cascaded H-Bridge Multilevel Converters for Large-Scale Photovoltaic Grid Integration," IEEE Transactions on Industrial Electronics, vol. 64, pp. 8877-8886, 2017.

[68] T. Arunkumari and V. Indragandhi, "An overview of high voltage conversion ratio DC-DC converter configurations used in DC micro-grid architectures," Renewable and Sustainable Energy Reviews, vol. 77, pp. 670-687, 2017/09/01/2017.

[69] M. Z. Hossain, N. A. Rahim, and J. a. 1. Selvaraj, "Recent progress and development on power DC-DC converter topology, control, design and applications: A review," Renewable and Sustainable Energy Reviews, vol. 81, pp. 205-230, 2018/01/01/2018.

[70] S. Sivakumar, M. J. Sathik, P. S. Manoj, and G. Sundararajan, "An assessment on performance of DC-DC converters for renewable energy applications," Renewable and Sustainable Energy Reviews, vol. 58, pp. 1475-1485, 2016/05/01/ 2016.

[71] S. Khosrogorji, M. Ahmadian, H. Torkaman, and S. Soori, "Multi-input DC/DC converters in connection with distributed generation units - A review," Renewable and Sustainable Energy Reviews, vol. 66, pp. 360-379, 2016/12/01/ 2016.

[72] B. Sri Revathi and M. Prabhakar, "Non isolated high gain DC-DC converter topologies for PV applications - A comprehensive review," Renewable and Sustainable Energy Reviews, vol. 66, pp. 920-933, 2016/12/01/ 2016.

[73] O. A. Ahmed and J. A. M. Bleijs, "An overview of DC-DC converter topologies for fuel cell-ultracapacitor hybrid distribution system," Renewable and Sustainable Energy Reviews, vol. 42, pp. 609-626, 2015/02/01/ 2015.

[74] M. V. Naik and P. Samuel, "Analysis of ripple current, power losses and high efficiency of DC-DC converters for fuel cell power generating systems," Renewable and Sustainable Energy Reviews, vol. 59, pp. 1080-1088, 2016/06/01/ 2016.

[75] Z. Rehman, I. Al-Bahadly, and S. Mukhopadhyay, "Multiinput DC-DC converters in renewable energy applications - An overview," Renewable and Sustainable Energy Reviews, vol. 41, pp. 521-539, 2015/01/01/ 2015.

[76] M. E. Başoğlu and B. Çakır, "Comparisons of MPPT performances of isolated and non-isolated DC-DC converters by using a new approach," Renewable and Sustainable Energy Reviews, vol. 60, pp. 1100-1113, 2016/07/01/ 2016.

[77] N. Zhang, D. Sutanto, and K. M. Muttaqi, "A review of topologies of three-port DC-DC converters for the integration of renewable energy and energy storage system," Renewable and Sustainable Energy Reviews, vol. 56, pp. 388-401, 2016/04/01/ 2016.

[78] M. H. Taghvaee, M. A. M. Radzi, S. M. Moosavain, H. Hizam, and M. Hamiruce Marhaban, "A current and future study on non-isolated DC-DC converters for photovoltaic applications," Renewable and Sustainable Energy Reviews, vol. 17, pp. 216-227, 2013/01/01/2013.

[79] G. Zhang, Z. Li, B. Zhang, and W. A. Halang, "Power electronics converters: Past, present and future," Renewable and Sustainable Energy Reviews, vol. 81, pp. 2028-2044, 2018/01/01/ 2018.

[80] R. Melício, V. M. F. Mendes, and J. P. S. Catalão, "Power converter topologies for wind energy conversion systems: Integrated modeling, control strategy and performance simulation," Renewable Energy, vol. 35, pp. 2165-2174, 2010/10/01/2010.

[81] R. W. Erickson, "Steady-State Equivalent Circuit Modeling, Losses, and Efficiency," in Fundamentals of Power Electronics, ed: Springer, 1997, pp. 40-61.

[82] W. Khadmun and W. Subsingha, "High voltage gain interleaved dc boost converter application for photovoltaic generation system," Energy Procedia, vol. 34, pp. 390-398, 2013.

[83] T.-F. Wu and T.-H. Yu, "Unified approach to developing single-stage power converters," IEEE transactions on aerospace and electronic systems, vol. 34, pp. 211-223, 1998. 
[84] Y. Zhao, W. Li, Y. Deng, X. He, S. Lambert, and V. Pickert, "High step-up boost converter with coupled inductor and switched capacitor," in Power Electronics, Machines and Drives (PEMD 2010), 5th IET International Conference on, 2010, pp. 1-6.

[85] Y. R. D. Novaes, I. Barbi, and A. Rufer, "A New Three-Level Quadratic (T-LQ) DC-DC Converter Suitable for Fuel Cell Applications," 電気学会論文誌 $D$ (産業応用部門誌), vol. 128, pp. 459-467, 2008.

[86] M. G. Bottarelli, I. Barbi, Y. R. De Novaes, and A. Rufer, "Three-level quadratic non-insulated basic DCDC converters," in Power Electronics and Applications, 2007 European Conference on, 2007, pp. 1-10.

[87] D. Maksimovic and R. Erickson, "Universal-input, high-power-factor, boost doubler rectifiers," in Applied Power Electronics Conference and Exposition, 1995. APEC'95. Conference Proceedings 1995., Tenth Annual, 1995, pp. 459-465.

[88] J. B. R. Cabral, T. L. da Silva, S. V. G. Oliveira, and Y. R. de Novaes, "A new high gain non-isolated DCDC boost converter for photovoltaic application," in 2013 Brazilian Power Electronics Conference, 2013, pp. 569-574.

[89] B. Axelrod, Y. Berkovich, and A. Ioinovici, "Switched-capacitor/switched-inductor structures for getting transformerless hybrid DC-DC PWM converters," Circuits and Systems I: Regular Papers, IEEE Transactions on, vol. 55, pp. 687-696, 2008.

[90] L.-S. Yang, T.-J. Liang, and J.-F. Chen, "Transformerless DC-DC converters with high step-up voltage gain," Industrial electronics, IEEE Transactions on, vol. 56, pp. 3144-3152, 2009.

[91] G. Wu, X. Ruan, and Z. Ye, "Nonisolated High Step-Up DC-DC Converters Adopting Switched-Capacitor Cell," Industrial Electronics, IEEE Transactions on, vol. 62, pp. 383-393, 2015.

[92] Y. Tang, T. Wang, and D. Fu, "Multicell Switched-Inductor/Switched-Capacitor Combined ActiveNetwork Converters," Power Electronics, IEEE Transactions on, vol. 30, pp. 2063-2072, 2015.

[93] L. Huber and M. M. Jovanovic, "A design approach for server power supplies for networking applications," in Applied Power Electronics Conference and Exposition, 2000. APEC 2000. Fifteenth Annual IEEE, 2000, pp. 1163-1169.

[94] X. Feng, J. Liu, and F. C. Lee, "Impedance specifications for stable DC distributed power systems," IEEE Transactions on Power Electronics, vol. 17, pp. 157-162, 2002.

[95] K. Gummi and M. Ferdowsi, "Synthesis of double-input DC-DC converters using a single-pole triple-throw switch as a building block," in Power Electronics Specialists Conference, 2008. PESC 2008. IEEE, 2008, pp. 2819-2823.

[96] V. A. K. Prabhala, D. Somayajula, and M. Ferdowsi, "Power sharing in a double-input buck converter using dead-time control," in Energy Conversion Congress and Exposition, 2009. ECCE 2009. IEEE, 2009, pp. 2621-2626.

[97] A. Amir, J. Selvaraj, and N. Rahim, "Study of the MPP tracking algorithms: Focusing the numerical method techniques," Renewable and Sustainable Energy Reviews, vol. 62, pp. 350-371, 2016.

[98] S. Lee, P. Kim, and S. Choi, "High step-up soft-switched converters using voltage multiplier cells," Power Electronics, IEEE Transactions on, vol. 28, pp. 3379-3387, 2013.

[99] C.-M. Young, M.-H. Chen, T.-A. Chang, C.-C. Ko, and K.-K. Jen, "Cascade Cockcroft-Walton voltage multiplier applied to transformerless high step-up DC-DC converter," Industrial Electronics, IEEE Transactions on, vol. 60, pp. 523-537, 2013.

[100] J. F. Dickson, "On-chip high-voltage generation in MNOS integrated circuits using an improved voltage multiplier technique," Solid-State Circuits, IEEE Journal of, vol. 11, pp. 374-378, 1976.

[101] V. Prabhala, P. Fajri, V. Gouribhatla, B. Baddipadiga, and M. Ferdowsi, "A Dc-Dc Converter with High Voltage Gain and Two Input Boost Stages."

[102] F. L. Luo and H. Ye, "Positive output super-lift converters," IEEE Transactions on power electronics, vol. 18, pp. 105-113, 2003.

[103] S. Zhang, J. Xu, and P. Yang, "A single-switch high gain quadratic boost converter based on voltage-lifttechnique," in 2012 10th International Power \& Energy Conference (IPEC), 2012, pp. 71-75.

[104] B. Axelrod, Y. Berkovich, A. Shenkman, and G. Golan, "Diode-capacitor voltage multipliers combined with boost-converters: topologies and characteristics," IET Power Electronics, vol. 5, pp. 873-884, 2012.

[105] Y. J. A. Alcazar, D. de Souza Oliveira, F. L. Tofoli, and R. P. Torrico-Bascope, "DC-DC nonisolated boost converter based on the three-state switching cell and voltage multiplier cells," Industrial Electronics, IEEE Transactions on, vol. 60, pp. 4438-4449, 2013.

[106] W. Li and X. He, "An interleaved winding-coupled boost converter with passive lossless clamp circuits," Power Electronics, IEEE Transactions on, vol. 22, pp. 1499-1507, 2007. 
[107] E. H. Ismail, M. A. Al-Saffar, A. J. Sabzali, and A. A. Fardoun, "High voltage gain single-switch nonisolated DC-DC converters for renewable energy applications," in Sustainable Energy Technologies (ICSET), 2010 IEEE International Conference on, 2010, pp. 1-6.

[108] A. A. Fardoun and E. H. Ismail, "Ultra step-up DC-DC converter with reduced switch stress," Industry Applications, IEEE Transactions on, vol. 46, pp. 2025-2034, 2010.

[109] Y. Zhao, X. Xiang, C. Li, Y. Gu, W. Li, and X. He, "Single-phase high step-up converter with improved multiplier cell suitable for half-bridge-based PV inverter system," Power Electronics, IEEE Transactions on, vol. 29, pp. 2807-2816, 2014.

[110] J.-K. Kim and G.-W. Moon, "Derivation, analysis, and comparison of nonisolated single-switch high stepup converters with low voltage stress," Power Electronics, IEEE Transactions on, vol. 30, pp. 1336-1344, 2015.

[111] Y. Zhang, J.-T. Sun, and Y.-F. Wang, "Hybrid boost three-level DC-DC converter with high voltage gain for photovoltaic generation systems," Power Electronics, IEEE Transactions on, vol. 28, pp. 3659-3664, 2013.

[112] L. H. S. C. Barreto, P. Peixoto Praca, D. S. Oliveira, and R. N. Silva, "High-voltage gain boost converter based on three-state commutation cell for battery charging using PV panels in a single conversion stage," Power Electronics, IEEE Transactions on, vol. 29, pp. 150-158, 2014.

[113] B. Wu, S. Li, Y. Liu, and K. M. Smedley, "A New Hybrid Boosting Converter for Renewable Energy Applications," Power Electronics, IEEE Transactions on, vol. 31, pp. 1203-1215, 2016.

[114] T.-F. Wu, Y.-S. Lai, J.-C. Hung, and Y.-M. Chen, "Boost converter with coupled inductors and buck-boost type of active clamp," in 2005 IEEE 36th Power Electronics Specialists Conference, 2005, pp. 399-405.

[115] L.-S. Yang, T.-J. Liang, H.-C. Lee, and J.-F. Chen, "Novel high step-up DC-DC converter with coupledinductor and voltage-doubler circuits," iEEE Transactions on industrial Electronics, vol. 58, pp. 41964206, 2011.

[116] J.-W. Baek, M.-H. Ryoo, T.-J. Kim, D.-W. Yoo, and J.-S. Kim, "High boost converter using voltage multiplier," in 31st Annual Conference of IEEE Industrial Electronics Society, 2005. IECON 2005., 2005, p. 6 pp.

[117] W. Li and X. He, "A Family of Interleaved DC-DC Converters DeducedFrom a Basic Cell With WindingCross-CoupledInductors (WCCIs) for High Step-Upor Step-Down Conversions," IEEE Transactions on Power Electronics, vol. 23, pp. 1791-1801, 2008.

[118] W. Li, Y. Zhao, Y. Deng, and X. He, "Interleaved converter with voltage multiplier cell for high step-up and high-efficiency conversion," IEEE Transactions on Power Electronics, vol. 25, pp. 2397-2408, 2010.

[119] S. V. Araújo, R. P. Torrico-Bascopé, and G. V. Torrico-Bascopé, "Highly efficient high step-up converter for fuel-cell power processing based on three-state commutation cell," IEEE transactions on industrial electronics, vol. 57, pp. 1987-1997, 2010.

[120] C.-T. Pan and C.-M. Lai, "A high-efficiency high step-up converter with low switch voltage stress for fuelcell system applications," IEEE Transactions on Industrial Electronics, vol. 57, pp. 1998-2006, 2010.

[121] W. Li, X. Xiang, C. Li, W. Li, and X. He, "Interleaved high step-up ZVT converter with built-in transformer voltage doubler cell for distributed PV generation system," IEEE Transactions on Power Electronics, vol. 28, pp. 300-313, 2013.

[122] K.-D. Kim, J.-G. Kim, Y.-C. Jung, and C.-Y. Won, "Improved non-isolated high voltage gain boost converter using coupled inductors," in Electrical Machines and Systems (ICEMS), 2011 International Conference on, 2011, pp. 1-6.

[123] R. Middlebrook, "A continuous model for the tapped-inductor boost converter," in Power Electronics Specialists Conference, 1975 IEEE, 1975, pp. 63-79.

[124] D. A. Grant, Y. Darroman, and J. Suter, "Synthesis of tapped-inductor switched-mode converters," IEEE Transactions on Power Electronics, vol. 22, pp. 1964-1969, 2007.

[125] T. Ahmed, S. Nagai, E. Hiraki, and M. Nakaoka, "A New Three Winding Coupled Inductor-Assisted High Frequency Boost Chopper Type DC-DC Power Converter with a High Voltage Conversion Ratio," Journal of Power Electronics, vol. 5, pp. 99-103, 2005.

[126] Y. Zhao, W. Li, and X. He, "Single-phase improved active clamp coupled-inductor-based converter with extended voltage doubler cell," IEEE Transactions on Power Electronics, vol. 27, pp. 2869-2878, 2012.

[127] R. Watson, F. C. Lee, and G. C. Hua, "Utilization of an active-clamp circuit to achieve soft switching in flyback converters," IEEE Transactions on Power Electronics, vol. 11, pp. 162-169, 1996. 
[128] F. S. Silva, A. A. Freitas, S. Daher, S. C. Ximenes, S. K. Sousa, M. Edilson, et al., "High gain DC-DC boost converter with a coupling inductor," in 2009 Brazilian Power Electronics Conference, 2009, pp. 486492.

[129] Q. Zhao and F. C. Lee, "High-efficiency, high step-up DC-DC converters," IEEE Transactions on Power Electronics, vol. 18, pp. 65-73, 2003.

[130] M. Muhammad, M. Armstrong, and M. Elgendy, "Non-isolated DC-DC converter for high-step-up ratio applications," in Power Electronics and Applications (EPE'15 ECCE-Europe), 2015 17th European Conference on, 2015, pp. 1-10.

[131] T.-F. Wu, Y.-S. Lai, J.-C. Hung, and Y.-M. Chen, "Boost converter with coupled inductors and buck-boost type of active clamp," in Power Electronics Specialists Conference, 2005. PESC'05. IEEE 36th, 2005, pp. $399-405$.

[132] Y. Zhao, W. Li, and X. He, "Single-phase improved active clamp coupled-inductor-based converter with extended voltage doubler cell," Power Electronics, IEEE Transactions on, vol. 27, pp. 2869-2878, 2012.

[133] Y.-P. Hsieh, J.-F. Chen, T.-J. Liang, and Y. Lung-Sheng, "Analysis and implementation of a novel singleswitch high step-up DC-DC converter," Power Electronics, IET, vol. 5, pp. 11-21, 2012.

[134] X. Hu and C. Gong, "A high gain input-parallel output-series DC/DC converter with dual coupled inductors," Power Electronics, IEEE Transactions on, vol. 30, pp. 1306-1317, 2015.

[135] X. Hu, G. Dai, L. Wang, and C. Gong, "A Three-State Switching Boost Converter Mixed With Magnetic Coupling and Voltage Multiplier Techniques for High Gain Conversion," Power Electronics, IEEE Transactions on, vol. 31, pp. 2991-3001, 2016.

[136] W. Li and X. He, "A Family of Interleaved DC-DC Converters DeducedFrom a Basic Cell With WindingCross-CoupledInductors (WCCIs) for High Step-Upor Step-Down Conversions," Power Electronics, IEEE Transactions on, vol. 23, pp. 1791-1801, 2008.

[137] K.-C. Tseng and C.-C. Huang, "High step-up high-efficiency interleaved converter with voltage multiplier module for renewable energy system," Industrial Electronics, IEEE Transactions on, vol. 61, pp. 13111319, 2014.

[138] M. Muhammad, M. Armstrong, and M. Elgendy, "A Non-isolated Interleaved Boost Converter for High Voltage Gain Applications."

[139] W. Li, Y. Zhao, J. Wu, and X. He, "Interleaved high step-up converter with winding-cross-coupled inductors and voltage multiplier cells," Power Electronics, IEEE Transactions on, vol. 27, pp. 133-143, 2012.

[140] A. Amir, A. Amir, J. Selvaraj, N. A. Rahim, and A. M. Abusorrah, "Conventional and modified MPPT techniques with direct control and dual scaled adaptive step-size," Solar Energy, vol. 157, pp. 1017-1031, 2017/11/15/ 2017.

[141] A. Amir, A. Amir, J. Selvaraj, and N. A. Rahim, "Study of the MPP tracking algorithms: Focusing the numerical method techniques," Renewable and Sustainable Energy Reviews, vol. 62, pp. 350-371, 2016/09/01/ 2016. 